I NTER NATIONAL MONETARY FUND
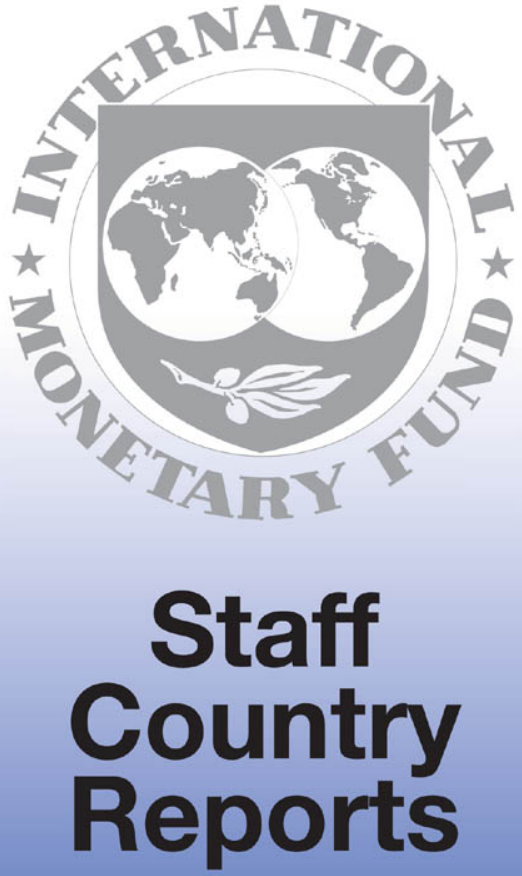


\section{South Africa: Detailed Assessment of Implementation on IOSCO Principles-Securities Markets}

This paper was prepared based on the information available at the time it was completed on October 21, 2010. The views expressed in this document are those of the staff team and do not necessarily reflect the views of the government of South Africa or the Executive Board of the IMF.

The policy of publication of staff reports and other documents by the IMF allows for the deletion of market-sensitive information.

Copies of this report are available to the public from

International Monetary Fund $\bullet$ Publication Services

700 19th Street, N.W. • Washington, D.C. 20431

Telephone: (202) 623-7430 • Telefax: (202) 623-7201

E-mail: publications@imf.org • Internet: http://www.imf.org

\section{International Monetary Fund Washington, D.C.}




\section{SOUTH AFRICA}

\section{IOSCO PRINCIPLES-SECURITIES MARKETS}

\section{DETAILED ASSESSMENT OF IMPLEMENTATION}

\section{OCTOBER 2010}

INTERNATIONAL MONETARY FUND

MONETARY AND CAPITAL MARKETS DEPARTMENT
THE WORLD BANK

FINANCIAL AND PRIVATE SECTOR DEVELOPMENT VICE PRESIDENCY

AFRICA REGIONAL VICE PRESIDENCY 
Glossary $\underline{3}$

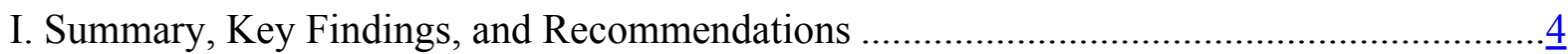

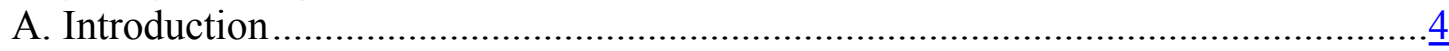

B. Information and Methodology Used for Assessment..............................................

C. Institutional and Market Structure - Overview .....................................................

D. Preconditions for Effective Securities Regulation................................................10

E. Recommended Action Plan and Authorities' Response......................................... $\frac{15}{16}$

F. Authorities' Response to the Assessment.................................................................

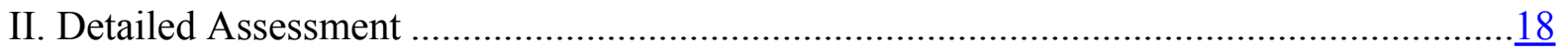

\section{Tables}

1. South Africa: Summary Implementation of the IOSCO Principles $\underline{11}$

2. Recommended Action Plan to Improve Implementation of the

3. South Africa: Detailed Assessment of Implementation of the. 


\section{GLOSSARY}

$\begin{array}{ll}\text { ABCP } & \text { Asset-backed commercial paper } \\ \text { ACI } & \text { Association of Collective Investments } \\ \text { APB } & \text { Accounting Policy Board } \\ \text { ASISA } & \text { Association for Savings and Investment in South Africa } \\ \text { BEE } & \text { Black Economic Empowerment shares } \\ \text { CFD } & \text { Contracts for difference } \\ \text { CISCA } & \text { Collective Investment Schemes Control Act of 2002 } \\ \text { CIPRO } & \text { Companies and Intellectual Property Commission } \\ \text { CIS } & \text { Collective investment scheme } \\ \text { DTI } & \text { Department of Trade and Industry } \\ \text { EO } & \text { Executive Officer of the FSB } \\ \text { FAIS } & \text { Financial Advisory and Intermediary Services Act } \\ \text { FIPFA } & \text { Financial Institution (Protection of Funds) Act of 2001 } \\ \text { FRIP } & \text { Financial Reporting Investigation Panel } \\ \text { FSAP } & \text { Financial Sector Assessment Program } \\ \text { FSB } & \text { Financial Services Board } \\ \text { FSP } & \text { Financial Service Providers } \\ \text { GMP } & \text { JSE GAAP Monitoring Panel } \\ \text { IASB } & \text { International Accounting Standards Board } \\ \text { IFIA } & \text { Inspections of Financial Institutions Act of 1998 } \\ \text { IFRS } & \text { International Financial Reporting Standards } \\ \text { IOSCO } & \text { International Organization of Securities Commissions } \\ \text { IRBA } & \text { Independent Regulatory Board for Auditors } \\ \text { ISA } & \text { International Standards on Auditing } \\ \text { JSE } & \text { Johannesburg Stock Exchange } \\ \text { LISP } & \text { Linked investment service providers } \\ \text { LSE } & \text { London Stock Exchange } \\ \text { MLAT } & \text { IOSCO Multilateral Memorandum of Understanding } \\ \text { OTC } & \text { Over the counter market } \\ \text { SARB } & \text { South African Reserve Bank } \\ \text { SENSJSE } & \text { Stock Exchange News Service } \\ \text { SRO } & \text { Self-regulatory organizations } \\ \text { SSA } & \text { Securities Services Act of 2004 } \\ \text { Standards Committee } & \text { Financial Reporting Standards Committee } \\ \text { Standards Council } & \text { Financial Reporting Standards Council } \\ \text { TRP } & \text { Takeover Regulation Panel } \\ & \end{array}$




\section{SUMMARY, KEY FINDINGS, AND RECOMMENDATIONS}

\section{South Africa has made substantial progress in addressing the recommendations of the 2000 FSAP and is continuing to build upon these} accomplishments. The legal authority of the Financial Services Board (FSB) has been greatly expanded through a series of new laws and it has expanded its staff to implement this new authority. In particular, violations of any law administered by the FSB, including insider trading, market misconduct and material misstatements by public companies, may now be sanctioned through an administrative tribunal, the Enforcement Committee. The FSB has also expanded its on-site examination program over registered entities and selfregulatory organizations (SROs) and is seeking the legal authority to oversee SRO listing requirements. During the past two years the FSB has adopted capital adequacy requirements for Financial Service Providers (FSP), and adopted minimum fit and proper requirements for FSP. The FSB is conscious that further development may be warranted. It is initiating a study of the South African over the counter market (OTC), and is assessing what legal authority is needed to properly regulate hedge funds and credit rating agencies, and what form of regulation would be appropriate. The Department of Trade and Industry (DTI) has the legal authority to register all companies in South Africa, including public companies and to set and enforce disclosure requirements and accounting standards. Significant amendments to the Companies Act dealing with this responsibility were enacted in 2007 and recently in 2009. DTI has not implemented the 2007 or 2009 amendments. Going forward, careful examination should be given to whether the authority and responsibility for these functions should continue in the DTI or be reassigned by Parliament to the FSB.

\section{A. Introduction}

1. This is an update of the IOSCO assessment that was performed in 2000 as part of the FSAP of South Africa. The update was performed by Mr. Jonathan Katz, a technical consultant to the IMF/World Bank FSAP mission. Mr. Katz was the Secretary of the US Securities and Exchange Commission for 20 years, until his retirement in 2006. Mr. Katz has performed nine other IOSCO assessments or assessment updates.

\section{B. Information and Methodology Used for Assessment}

2. The assessment was prepared on the basis of a self-assessment prepared by the FSB, public information contained on the FSB website and the websites of other entities in South Africa, and a review of relevant South African laws and regulations and interviews. Mr. Katz interviewed numerous staff of the FSB, as well as other governmental officials, representatives of South African self-regulatory organizations and private sector professionals working in the capital markets in South Africa. These 
interviews were conducted over a two week period in May, 2008. In March, 2010 this assessment was updated to reflect legal and regulatory changes made in the past two years. Additional interviews were conducted with FSB staff, staff of the Johannesburg Stock Exchange (JSE), Strate, DTI, and professionals in the financial services sector. Compliance with each principle as of 2010 was assessed using the four level methodology adopted by IOSCO_fully implemented, broadly implemented, partly implemented, and not implemented. In preparing the detailed assessment, Mr. Katz relied upon the IOSCO Assessment Methodology for guidance on the subjects to be examined for each principle, which provides key questions to help ensure consistency and the criteria for assessing implementation.

3. The timely completion of this assessment was greatly facilitated by the cooperation provided by numerous members of the staff of the FSB. The FSB staff was extremely generous with their time, their willingness to provide detailed answers to questions, and their assistance in arranging interviews with persons in the private sector. Staff of the JSE, Strate, and other organizations interviewed were similarly helpful with their explanations and commentary and equally generous with their time.

\section{Institutional and Market Structure-Overview}

4. The Financial Services Board (FSB) was established in 1990 with the enactment of the Financial Services Board Act (FSB Act). It regulates and supervises the non-bank part of the financial services industry, advises the Minister of Finance on matters concerning financial institutions and financial services, and informs and educates users and potential users of financial products and services. The FSB is subject to the general authority of the Minister of Finance who appoints the members of the Board and selects the senior officers, after consultation with the Board. The responsibilities of the FSB are clearly articulated in the FSB Act and in a series of related laws that have expanded the duties and powers of the FSB.

5. The FSB has broad regulatory authority over the JSE, (including SAFCOM, its clearance and settlement subsidiary), Strate, financial advisors and intermediaries (FAIS), collective investment scheme (CIS) operators, pension funds and insurance companies. It has clear authority to perform on-site examinations, to require reports and to investigate misconduct and to impose sanctions for violations of applicable laws.

6. Other governmental agencies in South Africa have responsibility for discrete regulatory functions that are included in the IOSCO principles. The Department of Trade and Industry (DTI) is responsible for the registration of all companies in South Africa, including public companies listed for trading in the secondary market. In 2007 the Corporate Laws Amendments Act established a Financial Reporting Standards Committee, to serve as the accounting standard setting body in South Africa and a Financial Reporting Investigation Panel to investigate non-compliance with financial reporting standards. Responsibility for creating the two groups was assigned to the DTI. As of March 2010, the two committees had not been formed. In the interim, in 2009, the 
Companies Act was again amended and the two panels were eliminated. These new amendments directed the DTI to create a Financial Reporting Standards Council, to set national accounting policy. A revamped Companies and Intellectual Property Commission has been authorized to perform the duties assigned to the Financial Reporting Investigation Panel. As of March 2010, neither entity has been established.

7. Authority to enforce South African laws concerning mergers, acquisitions and changes in corporate control resides with the Takeover Regulation Panel (TRP, formerly Securities Regulation Panel), an entity created by the Companies Act of 1973 (this law was amended in 2007 and in 2009). As currently structured, the TRP is appointed by the Minister of DTI, but functions independently.

8. The Financial Intelligence Centre is a separate unit in the National Treasury responsible for anti-money laundering regulation.

9. The South African Reserve Bank (SARB), the nation's central bank, has certain relevant regulatory duties. While the FSB has responsibility for licensing bank subsidiaries engaged in brokerage or other non-bank financial services, the underwriting of securities in South Africa typically is performed directly by the merchant/investment banking department of a bank, or a specialized merchant/investment bank. As such, SARB has regulatory responsibility for this function. Also, SARB, through its foreign exchange control authority, has responsibility for approving cross-border dual listings and foreign securities offerings as part of its currency exchange control responsibilities.

10. The South African regulatory scheme also includes several statutory advisory boards that provide input to the Minister of Finance or FSB on strategic and policy objectives. These include the Policy Board for Financial Services Regulation (Policy Board), the Financial Markets Advisory Board, the Collective Investment Scheme Advisory Committee, the Advisory Committee on Financial Services Providers, and several other committees concerned with other segments of the financial services sector, but not pertinent to the areas covered by the IOSCO principles. Also a Standing Advisory Committee on Company Law advises the Minister of Trade and Industry on company law matters. In total there are ten advisory committees and four standing committees that play a role in regulating the financial sector in South Africa.

11. As noted previously, the authority of the FSB has grown significantly since the 2000 FSAP. The Securities Services Act of 2004 (SSA) expanded the FSB's enforcement authority. FSB enforcement authority was enhanced again in 2008 by an amendment of the Financial Institution (Protection of Funds) Act of 2001. This Act expanded the jurisdiction of the Enforcement Committee to adjudicate any violation of a law administered by the FSB. The Collective Investment Schemes Control Act of 2002 (CISCA) and the Financial Advisory and Intermediary Services Act of 2002 (FAIS) expanded the authority of the FSB to register, regulate, and inspect asset managers, 
financial advisors (excluding stockbrokers and authorized users already regulated by the JSE), and collective investment schemes. The Corporate Laws Amendment Act of 2007 addressed several recommendations of the 2002 Accounting and Auditing ROSC.

12. Self-regulatory organizations (SRO) are critical components of the regulatory system. The JSE is the primary and secondary market for listed equity securities, financial derivatives, agricultural commodities and a recently developed bond market. In 2009, the Bond Exchange of South Africa (BESA), which had been the principal bond exchange, merged with the JSE. The JSE now operates YieldX as the trading platform and trade reporting service for listed South African debt securities. The JSE is a licensed self-regulatory organization (SRO) and has primary regulatory responsibility for licensing members (authorized users) and employees and setting listing standards and disclosure obligations for listed companies. It also has lead responsibility for market surveillance and has the authority to take disciplinary action against member firms and their employees and listed companies and company directors. Firms and employees registered with the JSE are exempt from registration with the FSB under FAIS with regard to activities directly regulated by the JSE. However a firm that provides other financial services not regulated by the JSE must also register with the FSB under FAIS and comply with FAIS.

13. The JSE acts as the primary regulatory body for setting and monitoring disclosure requirements for its public listed companies. While the DTI has broad legal authority in this area, traditionally it has focused its resources on its function as company registrar of all companies in South Africa (public and private) and deferred to the JSE to regulate disclosure of its listed companies. However, in South Africa a company may directly offer its shares to the public and have public shareholders without being listed on a stock exchange. The company may subsequently buy back its shares and directly resell them. However it is illegal for a broker or other intermediary to act as a market-maker and effect secondary market trading in these public, unlisted companies.

14. Strate is a licensed SRO that functions as the central securities depository (CSD) for both listed equity securities and debt (government and corporate) and some unlisted securities, primarily commercial paper. It also acts as a clearinghouse for some debt trading. SAFCOM, a wholly owned subsidiary of the JSE, is a licensed clearinghouse for derivatives listed on the JSE.

15. Mutual funds are called collective investment schemes (formerly referred to as unit trusts) in South Africa. The industry has grown significantly with total assets under management valued at R786.1billion as of the end of 2009. This represents 19 percent growth from the previous year. Of the R786.1 billion at December 2009, money market funds represent 30.3 percent. There were 936 funds, down from 939 in December 2008. CIS are directly regulated by the FSB, which has an extensive regulatory scheme focused on initial registration, capital adequacy and operating compliance. Broad CIS investor disclosure and marketing obligations are contained in section 3 of CISCA. Industry implementation and compliance with this principle rests largely on non-binding industry codes of conduct. These codes were initially drafted by the Association of Collective 
Investments (ACI), a voluntary industry organization that declined to apply and be licensed as an SRO. In 2009, the ACI merged into a new broader industry trade group the Association for Savings and Investment in South Africa (ASISA). FSB staff believe that these standards are advisory and do not constitute legally binding requirements. However, in the absence of other regulatory standards, these codes are the de facto standard.

16. The JSE is the $19^{\text {th }}$ largest equity market in the world, with a market capitalization equivalent to 200 percent of GDP. As of 2009 , there were 54 equity member firms of the JSE and 419 companies had listed shares. The average number of equity trades per day was more than $83,800 .{ }^{1}$ The JSE also operates as the national derivatives exchange and, following the merger with BESA, a bond trading exchange. It has a well-developed trading market in single stock futures. The equity market is readily accessible to nonresidents, in particular following the "head of terms" agreement between the Johannesburg and the London Stock Exchange of 2002. The JSE uses the LSE trading system.

17. The JSE remains highly concentrated, with just 70 stocks accounting for 85 percent of its market capitalization. There is also considerable sectoral concentration: mining stocks account for around 40 percent of the JSE's market value, with financial services stocks accounting for a further 20 percent. In October 2003 the JSE launched a new equity market for smaller, emerging public companies called AltX. This market caters to small and medium-sized companies, and listing requirements are less stringent. Between 2007 and 2010, the number of listed companies grew from 57 to 76 . During the same period, the AltX total market grew from R 17 billion to 21.4 billion. The JSE has also created two more new trading boards. One board will list companies incorporated in neighboring African countries. One such company has listed and another is planning to list. The second new board lists single stock futures in foreign companies, enabling South African investors to invest in foreign companies easily. Recently the JSE announced that it is considering creation of a third new board to permit companies that have issued socalled "black economic empowerment" (BEE) shares to list these securities separately and facilitate better transparency in secondary market trading in these shares.

18. The initial offering process for equity securities is under the regulation of the DTI and the JSE exercises primary responsibility through its listing requirements. As banks are the principal underwriter of securities in Africa, SARB could also play a role in regulating this activity. It is estimated that over half of all public offerings are selfunderwritten by the company issuing the securities, with marketing and distribution occurring by stockbrokers or financial intermediaries. The JSE requires listed companies to retain the services of a company sponsor (main board stocks) or a company designated

\footnotetext{
${ }^{1}$ Data obtained from the January 13, 2010 JSE Market Profile Report. In 2009 20,950,750 trades occurred over 250 trading days.
} 
advisor (Altx) who is responsible for conducting due diligence in the offering and ongoing advice to the company on regulatory responsibilities. The sponsor or advisor also must advise the JSE in appropriate circumstances.

19. There is little regulatory oversight of the over the counter market. A very large OTC market exists for derivatives and a small but growing market exists for interest rate swap/derivatives. There is very little available information on the size or extent of trading activity in the OTC equities market for unlisted companies. In 2010, the FSB determined to initiate a study of OTC trading in derivatives to determine which OTC instruments should be regulated, and if so, how they should be regulated. A private consultant has been retained to lead the study.

20. The domestic bond market has been growing. The JSE bond platform is the trading market for government, local government and domestic corporation ZARdenominated debt. In fact, while the JSE provides some small amount of indicative bids and offers for listed securities, secondary market trading in debt securities is largely an OTC market dominated by the leading South African banks. All trading must be reported to the JSE for publication. As of 2009 1,087 bond issues were listed by 104 issuers with a total nominal value of $\mathrm{R} 827.7$ billion. Sovereign government debt represented 53 percent of nominal value and corporate issues accounted for 33 percent of nominal value.

21. While securitization was a slowly growing market segment through 2007 , the international financial crisis has temporarily stalled this growth. The market overall remains limited (US\$6.2 billion at the beginning of 2008) and represents a very small share of banks' balance sheets (less than 2 percent of bank assets). Banks also use assetbacked commercial paper (ABCP) conduits to fund origination of corporate loans. As is the case in other markets, the largest banks are the main players in securitization and ABCP markets.

22. In 2010, an electronic money market program began operation. This project has been led by Strate and is designed to facilitate trade reporting and the bilateral clearance and settlement of short-term debt instruments. At present, the system does not provide any facilities for order exposure.

23. The foreign exchange (forex) markets are comparatively well developed as measured by turnover to GDP ratio. While the spot market is middle-of-the-range the forex derivatives market is one of the largest. The spot market is served by 26 authorized dealers including all major commercial and investment banks plus the foreign banks. The derivatives market is dominated by one-week forex swap transactions. At least two thirds of forex market transactions are with nonresident dealers.

24. There is a developing hedge fund industry in South Africa, with assets under management estimated at approximately R 30 billion with approximately R 14 billion additional under management by funds of hedge funds. Under South African law there is 
no concept of a "sophisticated" or "qualified high net worth" investor. Because CISCA does not provide the FSB with the authority to exempt entities from specific requirements of the law, these pools of assets cannot be structured as collective investment schemes (although the asset managers must be licensed under FAIS). Because South African law does not prescribe a particular structure for the hedge fund management entity, hedge funds may be structured in different ways, such as a pooled investment in limited partnerships or as a company that issues interests that are termed debentures or promissory notes. An investment in a hedge fund may also be made via an insurance company product that invests in the hedge fund. These policies (minimum five years) provide a return pegged to the total return of the hedge fund pool of assets identified in the policy.

\section{Preconditions for Effective Securities Regulation}

25. The South African capital markets have benefited from a strong legal infrastructure. It has a well-established judiciary that is perceived to be competent and independent. Its commercial laws and debtor-creditor laws are believed to be sound. South Africa was one of the first countries to adopt the International Financial Reporting Standards promulgated by the International Accounting Standards Board. 


\section{Table 1. South Africa: Summary Implementation of the IOSCO Principles}

\begin{tabular}{|c|c|c|}
\hline Principle & Rating & Findings \\
\hline $\begin{array}{l}\text { Principle 1. The responsibilities } \\
\text { of the regulator should be } \\
\text { clearly and objectively stated }\end{array}$ & $\mathrm{FI}$ & $\begin{array}{l}\text { The South African system of financial services regulation is } \\
\text { complex, involving multiple government agencies, several } \\
\text { advisory or oversight committees, and several self- } \\
\text { regulatory organizations. }\end{array}$ \\
\hline $\begin{array}{l}\text { Principle } 2 \text {. The regulator } \\
\text { should be operationally } \\
\text { independent and accountable } \\
\text { in the exercise of its functions } \\
\text { and powers }\end{array}$ & $\mathrm{BI}$ & $\begin{array}{l}\text { The FSB has full control over its budget and daily } \\
\text { operations. However the Minister of Finance has the legal } \\
\text { authority to hire and fire Board members and FSB executive } \\
\text { staff. }\end{array}$ \\
\hline $\begin{array}{l}\text { Principle } 3 . \text { The regulator } \\
\text { should have adequate powers, } \\
\text { proper resources and the } \\
\text { capacity to perform its } \\
\text { functions and exercise its } \\
\text { powers }\end{array}$ & $\mathrm{BI}$ & $\begin{array}{l}\text { Since the } 2000 \text { assessment the FSB has obtained greatly } \\
\text { expanded legal authority and has succeeded in building its } \\
\text { capacity to exercise these responsibilities. The FSB lacks } \\
\text { regulatory authority to set disclosure requirements for public } \\
\text { companies. This responsibility is assigned the DTI for all } \\
\text { companies and to the JSE, which includes disclosure } \\
\text { requirements for listed companies in its listing standards. } \\
\text { The DTI subsidiaries charged with these responsibilities in } \\
2007 \text { were never operational and have been replaced by } \\
\text { new entities, which are not yet operating. }\end{array}$ \\
\hline $\begin{array}{l}\text { Principle } 4 \text {. The regulator } \\
\text { should adopt clear and } \\
\text { consistent regulatory } \\
\text { processes }\end{array}$ & $\mathrm{FI}$ & $\begin{array}{l}\text { The FSB has sound internal operating processes. Its internal } \\
\text { processes have received ISO } 9000 \text { certification. }\end{array}$ \\
\hline $\begin{array}{l}\text { Principle } 5 . \text { The staff of the } \\
\text { regulator should observe the } \\
\text { highest professional standards }\end{array}$ & $\mathrm{FI}$ & $\begin{array}{l}\text { The FSB has a code of conduct, that is in the process of } \\
\text { being revised, for its employees that addresses } \\
\text { confidentiality of information, receipt of gifts from licensed } \\
\text { entities and ownership of securities. }\end{array}$ \\
\hline $\begin{array}{l}\text { Principle } 6 \text { The regulatory } \\
\text { regime should make } \\
\text { appropriate use of self- } \\
\text { regulatory organizations } \\
\text { (SROs) that exercise some } \\
\text { direct oversight responsibility } \\
\text { for their respective areas of } \\
\text { competence and to the extent } \\
\text { appropriate to the size and } \\
\text { complexity of the markets }\end{array}$ & $\begin{array}{l}\text { No } \\
\text { Rating }\end{array}$ & $\begin{array}{l}\text { The JSE and Strate perform several core regulatory } \\
\text { functions. The ASISA, an industry trade group performs } \\
\text { certain regulatory functions, but is not an SRO, subject to } \\
\text { FSB oversight. }\end{array}$ \\
\hline
\end{tabular}

Principle 7. SROs should be subject to the oversight of the regulator and should observe standards of fairness and confidentiality when exerc ising powers and delegated responsibilities
BI

The FSB has broad authority to license, subject to annual renewal, its SRO's. Only the JSE and Strate are currently licensed. The FSB does not have, but is seeking to obtain, review and approval authority over JSE listing requirements. 


\begin{tabular}{|c|c|c|}
\hline $\begin{array}{l}\text { Principle } 8 . \text { The regulator } \\
\text { should have comprehensive } \\
\text { inspection, investigation and } \\
\text { surveillance powers }\end{array}$ & $\mathbf{F I}$ & $\begin{array}{l}\text { The FSB has strong inspection and investigation powers } \\
\text { and the JSE provides it with surveillance capacity over the } \\
\text { listed market. }\end{array}$ \\
\hline $\begin{array}{l}\text { Principle } 9 . \text { The regulator } \\
\text { should have comprehensive } \\
\text { enforcement powers }\end{array}$ & FI & $\begin{array}{l}\text { The FSB has expanded its ability to bring enforcement } \\
\text { actions administratively and it may now use the Enforcement } \\
\text { Committee process to impose substantial sanctions for any } \\
\text { violation of the acts administered by the FSB. In recent } \\
\text { years, the FSB has built a robust investigation and } \\
\text { enforcement program, with many notable accomplishments. }\end{array}$ \\
\hline $\begin{array}{l}\text { Principle 10. The regulatory } \\
\text { system should ensure an } \\
\text { effective and credible use of } \\
\text { inspection, investigation, } \\
\text { surveillance and enforcement } \\
\text { powers and implementation of } \\
\text { an effective compliance } \\
\text { program. }\end{array}$ & FI & $\begin{array}{l}\text { The FSB has greatly expanded its inspection and } \\
\text { investigation program since the } 2000 \text { assessment. It has } \\
\text { also developed a strong enforcement program based upon } \\
\text { the expanded authority of its Enforcement Committee } \\
\text { system to adjudicate and sanction violations. There is limited } \\
\text { surveillance capacity over OTC activities of registered } \\
\text { intermediaries. This will be examined as part of an FSB } \\
\text { study on the operation and regulation of the OTC market. } \\
\text { The DTI agencies empowered to investigate financial } \\
\text { reporting violations have not begun operations. }\end{array}$ \\
\hline $\begin{array}{l}\text { Principle } 11 \text { The regulator } \\
\text { should have the authority to } \\
\text { share both public and non- } \\
\text { public information with } \\
\text { domestic and foreign } \\
\text { counterparts }\end{array}$ & FI & $\begin{array}{l}\text { The FSB has full legal authority to share information with } \\
\text { domestic and foreign regulators. }\end{array}$ \\
\hline $\begin{array}{l}\text { Principle 12. Regulators should } \\
\text { establish information sharing } \\
\text { mechanisms that set out when } \\
\text { and how they will share both } \\
\text { public and non-public } \\
\text { information with their domestic } \\
\text { and foreign counterparts }\end{array}$ & FI & $\begin{array}{l}\text { The FSB has written agreements to share information with } \\
\text { the SARB and the Revenue Authority. The FSB also has } \\
\text { entered into } 50 \text { bilateral MOUs with foreign regulatory } \\
\text { authorities and is a signatory to the IOSCO MMOU. }\end{array}$ \\
\hline $\begin{array}{l}\text { Principle 13. The regulatory } \\
\text { system should allow for } \\
\text { assistance to be provided to } \\
\text { foreign regulators who need to } \\
\text { make inquiries in the discharge } \\
\text { of their functions and exercise } \\
\text { of their powers }\end{array}$ & FI & $\begin{array}{l}\text { The FSB is a signatory to the IOSCO multi-lateral } \\
\text { memorandum of understanding on information sharing. }\end{array}$ \\
\hline
\end{tabular}




\begin{tabular}{|c|c|c|}
\hline $\begin{array}{l}\text { Principle 14. There should be } \\
\text { full, timely and accurate } \\
\text { disclosure of financial results } \\
\text { and other information that is } \\
\text { material to investors' decisions }\end{array}$ & PI & $\begin{array}{l}\text { Current disclosure standards provide investors with } \\
\text { necessary information on public companies. Responsibility } \\
\text { for setting disclosure requirements is assigned to the DTI for } \\
\text { all companies and to the JSE, through its listing } \\
\text { requirements, for listed companies. While DTI and JSE } \\
\text { review initial offering documents, such as prospectuses, and } \\
\text { documents relating to acquisitions and special transactions, } \\
\text { neither entity routinely reviews periodic disclosure reports, } \\
\text { such as annual reports. These documents may be reviewed } \\
\text { when a complaint is received. Regulatory systems for } \\
\text { proactively reviewing periodic company disclosures could be } \\
\text { improved. }\end{array}$ \\
\hline $\begin{array}{l}\text { Principle } 15 . \text { Holders of } \\
\text { securities in a company should } \\
\text { be treated in a fair and } \\
\text { equitable manner }\end{array}$ & BI & $\begin{array}{l}\text { The King Commission reports have contributed to an } \\
\text { improved system of corporate governance and } \\
\text { accountability. While proxy solicitation is provided for in the } \\
2009 \text { Companies Act amendments, there are no procedures } \\
\text { in placing governing a proxy solicitation. }\end{array}$ \\
\hline $\begin{array}{l}\text { Principle } 16 . \text { Accounting and } \\
\text { auditing standards should be of } \\
\text { a high and internationally } \\
\text { acceptable quality }\end{array}$ & BI & $\begin{array}{l}\text { South Africa was an early adopter of IFRS. There is a } \\
\text { national system for oversight of the accounting and auditing } \\
\text { profession. DTI has not yet created the governmental body } \\
\text { to set national accounting policy. }\end{array}$ \\
\hline $\begin{array}{l}\text { Principle } 17 . \text { The regulatory } \\
\text { system should set standards } \\
\text { for the eligibility and the } \\
\text { regulation of those who wish to } \\
\text { market or operate a collective } \\
\text { investment scheme }\end{array}$ & FI & $\begin{array}{l}\text { CISCA and FAIS provide the FSB with broad regulatory } \\
\text { authority and the FSB has successfully addressed its } \\
\text { responsibilities. Consideration should be given to issues } \\
\text { raised by white label funds. }\end{array}$ \\
\hline $\begin{array}{l}\text { Principle } 18 . \text { The regulatory } \\
\text { system should provide for rules } \\
\text { governing the legal form and } \\
\text { structure of collective } \\
\text { investment schemes and the } \\
\text { segregation and protection of } \\
\text { client assets }\end{array}$ & BI & $\begin{array}{l}\text { CISCA established a strong regulatory framework for CIS. } \\
\text { The FSB has used its licensing authority to address issues } \\
\text { concerning segregation of investor assets in LISPs. Legal } \\
\text { gaps complicate the development of a legal form for hedge } \\
\text { funds. }\end{array}$ \\
\hline $\begin{array}{l}\text { Principle 19. Regulation should } \\
\text { require disclosure, as set forth } \\
\text { under the principles for issuers, } \\
\text { which is necessary to evaluate } \\
\text { the suitability of a collective } \\
\text { investment scheme for a } \\
\text { particular investor and the } \\
\text { value of the investor's interest } \\
\text { in the scheme }\end{array}$ & $\mathbf{P I}$ & $\begin{array}{l}\text { While FAIS establishes a legal standard requiring CIS to } \\
\text { provide investors with necessary information, the only } \\
\text { specific disclosure requirements are non-binding industry } \\
\text { codes. }\end{array}$ \\
\hline $\begin{array}{l}\text { Principle } 20 . \text { Regulation should } \\
\text { ensure that there is a proper } \\
\text { and disclosed basis for assets } \\
\text { valuation and the pricing and } \\
\text { the redemption of units in a } \\
\text { collective investment scheme }\end{array}$ & FI & Regulation of CIS valuation and pricing is sound. \\
\hline
\end{tabular}




\begin{tabular}{|c|c|c|}
\hline $\begin{array}{l}\text { Principle } 21 . \text { Regulation should } \\
\text { provide for minimum entry } \\
\text { standards for market } \\
\text { intermediaries }\end{array}$ & FI & $\begin{array}{l}\text { The FSB has developed a comprehensive licensing system } \\
\text { implementing its authority under FAIS and CISCA. }\end{array}$ \\
\hline $\begin{array}{l}\text { Principle 22. There should be } \\
\text { initial and ongoing capital and } \\
\text { other prudential requirements } \\
\text { for market intermediaries that } \\
\text { reflect the risks that the } \\
\text { intermediaries undertake }\end{array}$ & BI & $\begin{array}{l}\text { The JSE capital adequacy standards for its licensed } \\
\text { members appear to be sound and the JSE BDA system } \\
\text { provides daily information on member firm open positions } \\
\text { and exposure. In } 2009 \text {, the FSB adopted capital adequacy } \\
\text { standards for FAIS registrants. An early warning system } \\
\text { under FAIS has not been created. }\end{array}$ \\
\hline $\begin{array}{l}\text { Principle 23. Market } \\
\text { intermediaries should be } \\
\text { required to comply with } \\
\text { standards for internal } \\
\text { organization and operational } \\
\text { conduct that aim to protect the } \\
\text { interests of clients, ensure } \\
\text { proper management of risk, } \\
\text { and under which management } \\
\text { of the intermediary accepts } \\
\text { primary responsibility for these } \\
\text { matters }\end{array}$ & BI & $\begin{array}{l}\text { FSB requires licensees to have internal control processes } \\
\text { and compliance officers. Firms may contract out this } \\
\text { responsibility to compliance companies approved by the } \\
\text { FSB. All client funds must be held in segregated accounts } \\
\text { and licensees must apply "know your customer" principles in } \\
\text { providing financial advice. }\end{array}$ \\
\hline $\begin{array}{l}\text { Principle 24. There should be a } \\
\text { procedure for dealing with the } \\
\text { failure of a market intermediary } \\
\text { in order to minimize damage } \\
\text { and loss to investors and to } \\
\text { contain systemic risk }\end{array}$ & FI & $\begin{array}{l}\text { The FSB and JSE have authority to order licensees to } \\
\text { suspend or terminate operations and the FSB may seek a } \\
\text { court order to appoint a curator. }\end{array}$ \\
\hline $\begin{array}{l}\text { Principle } 25 . \text { The } \\
\text { establishment of trading } \\
\text { systems including securities } \\
\text { exchanges should be subject } \\
\text { to regulatory authorization and } \\
\text { oversight }\end{array}$ & FI & $\begin{array}{l}\text { The SSA provides comprehensive requirements for } \\
\text { registration of an exchange. The FSB effectively oversees } \\
\text { the operations of the JSE. }\end{array}$ \\
\hline $\begin{array}{l}\text { Principle } 26 \text {. There should be } \\
\text { ongoing regulatory supervision } \\
\text { of exchanges and trading } \\
\text { systems, which should aim to } \\
\text { ensure that the integrity of } \\
\text { trading is maintained through } \\
\text { fair and equitable rules that } \\
\text { strike an appropriate balance } \\
\text { between the demands of } \\
\text { different market participants }\end{array}$ & $\mathbf{F I}$ & $\begin{array}{l}\text { The JSE license must be renewed annually. As part of the } \\
\text { renewal process the JSE must submit a written self- } \\
\text { assessment form and the FSB annually performs an on-site } \\
\text { examination. On-going market surveillance is performed by } \\
\text { JSE, with FSB staff oversight through weekly meetings and } \\
\text { reports and regular informal contact. }\end{array}$ \\
\hline $\begin{array}{l}\text { Principle 27. Regulation should } \\
\text { promote transparency of } \\
\text { trading }\end{array}$ & BI & $\begin{array}{l}\text { The systems in South Africa for trading in listed securities } \\
\text { are robust and comparable to international best practices. } \\
\text { Trading in the OTC market, which is substantial in certain } \\
\text { derivative products, is unsupervised. In } 2010 \text { the FSB } \\
\text { initiated a study of the OTC market. }\end{array}$ \\
\hline
\end{tabular}




\begin{tabular}{|l|c|l|}
\hline $\begin{array}{l}\text { Principle 28. Regulation should } \\
\text { be designed to detect and } \\
\text { deter manipulation and other } \\
\text { unfair trading practices }\end{array}$ & FI & $\begin{array}{l}\text { Relying upon JSE listed market surveillance, the FSB has } \\
\text { developed a strong investigative program covering insider } \\
\text { trading, market manipulation and corporate disclosure. } \\
\text { Consideration should be given to the need for market } \\
\text { surveillance in the OTC market and expansion of its } \\
\text { investigation and enforcement program into OTC market } \\
\text { misconduct. }\end{array}$ \\
\hline $\begin{array}{l}\text { Principle 29. Regulation should } \\
\text { aim to ensure the proper } \\
\text { management of large } \\
\text { exposures, default risk and } \\
\text { market disruption }\end{array}$ & BI & $\begin{array}{l}\text { The JSE BDA system provides it with robust data on } \\
\text { member firm exposures. Both the JSE and FSB have the } \\
\text { power to take action in the event of a firm failure to avoid } \\
\text { systemic failures. }\end{array}$ \\
\hline $\begin{array}{l}\text { Principle 30. Systems for } \\
\text { clearing and settlement of } \\
\text { securities transactions should } \\
\text { be subject to regulatory } \\
\text { oversight, and designed to } \\
\text { ensure that they are fair, } \\
\text { effective and efficient and that } \\
\text { they reduce systemic risk }\end{array}$ & $\begin{array}{l}\text { Not } \\
\text { rated } \\
\text { as a } \\
\text { full } \\
\text { CPSS/ } \\
\text { IOSCO } \\
\text { review } \\
\text { not } \\
\text { perfor- } \\
\text { med }\end{array}$ & $\begin{array}{l}\text { While the JSE is not legally designated a central } \\
\text { counterparty, it performs a comparable function by acting as } \\
\text { guarantor of all trading on its market. Its system for } \\
\text { clearance and settlement has a strong record, largely } \\
\text { because the JSE may call in replacement securities to cover } \\
\text { a delivery failure. At present it operates on a T+5 standard } \\
\text { for equities and a T+3 for debt. Conversion to a T+3 } \\
\text { standard for equities is a priority, but cannot be implemented } \\
\text { until the JSE completes a large IT system replacement } \\
\text { program, which has been delayed. }\end{array}$ \\
\hline
\end{tabular}

Aggregate: Fully implemented $(\mathrm{FI})-16$, broadly implemented $(\mathrm{BI})-11$, partly implemented $(\mathrm{PI})-2$, not implemented $(\mathrm{NI})-0$, not applicable (N/A) - 0 .

\section{E. Recommended Action Plan and Authorities' Response}

\section{Table 2. South Africa: Recommended Action Plan to Improve Implementation of the IOSCO Principles}

\begin{tabular}{|l|l|}
\hline \multicolumn{1}{|c|}{ Principle } & \multicolumn{1}{c|}{ Recommended Action } \\
\hline Principle 2 & $\begin{array}{l}\text { The unlimited discretion of the Minister of Finance to terminate } \\
\text { senior FSB staff and members of the FSB Board should be } \\
\text { defined and limited to circumstances where there is "good } \\
\text { cause." }\end{array}$ \\
\hline Principle 5 & $\begin{array}{l}\text { The FSB should complete the proposed revisions to its rules } \\
\text { for employees to report securities trading, the receipt of gifts } \\
\text { from the industry, and negotiations for employment with } \\
\text { regulated entities. }\end{array}$ \\
\hline Principle 7 & $\begin{array}{l}\text { The FSB should obtain legal authority to formally review and } \\
\text { approve JSE listing standards. This authority is included in a } \\
\text { package of proposed amendments to the SSA to be submitted } \\
\text { to Parliament in 2010. The status of ASISA should be clarified. } \\
\text { If ASISA intends to monitor and police industry compliance } \\
\text { with its codes, then ASISA should apply for an SRO license. }\end{array}$ \\
\hline Phe CTI must empanel the Companies Tribunal. DTI/CIPRO \\
must establish a credible program to enforce the Companies \\
Act.
\end{tabular}




\begin{tabular}{|c|c|}
\hline Principle & Recommended Action \\
\hline Principle 14 & $\begin{array}{l}\text { The JSE should pro-actively monitor ongoing periodic } \\
\text { company disclosure reports. If the DTI does not implement its } \\
\text { legal responsibility to monitor compliance by public companies } \\
\text { with the Companies Act, this authority should be legally } \\
\text { transferred to the FSB. }\end{array}$ \\
\hline Principle 15 & $\begin{array}{l}\text { While the Companies Act permits shareholders to provide } \\
\text { proxies to third parties, there is no regulatory scheme } \\
\text { governing the process for soliciting proxies by third parties. } \\
\text { Company officers should be required to disclose transactions } \\
\text { in the company's securities. }\end{array}$ \\
\hline Principle 16 & $\begin{array}{l}\text { Public companies should be required to publicly disclose any } \\
\text { IRBA notice of accounting irregularities. DTI should quickly } \\
\text { create the Financial Reporting Standards Council and provide } \\
\text { it with sufficient resources to perform its responsibilities. }\end{array}$ \\
\hline Principle 18 & $\begin{array}{l}\text { The FSB should complete action on its initiative to develop a } \\
\text { clear legal form for hedge funds, and, as appropriate, an } \\
\text { effective regulatory environment for hedge funds. }\end{array}$ \\
\hline Principle 19 & $\begin{array}{l}\text { The FSB should examine the ASISA codes for marketing and } \\
\text { disclosure by CIS. If the FSB determines them to be } \\
\text { appropriate these codes should be formally adopted as an } \\
\text { FSB directive. }\end{array}$ \\
\hline Principle 21 & $\begin{array}{l}\text { Consideration should be given to creating a new subcategory } \\
\text { under FAIS for CIS portfolio managers. }\end{array}$ \\
\hline Principle 22 & $\begin{array}{l}\text { The capital adequacy requirements under FAIS should require } \\
\text { more frequent calculation of capital and an early warning } \\
\text { notification obligation. }\end{array}$ \\
\hline Principle 23 & $\begin{array}{l}\text { The FSB should consider creating minimum service level } \\
\text { requirements for FSPs who rely upon contract compliance } \\
\text { companies. Consideration should also be given to establishing } \\
\text { minimum resource requirements for compliance companies on } \\
\text { a per client basis. The FAIS division of FSB should obtain the } \\
\text { authority to perform on-site visits of third party compliance } \\
\text { companies. A bill amending the FAIS to provide this authority } \\
\text { has been submitted to Parliament. }\end{array}$ \\
\hline Principle 30 & $\begin{array}{l}\text { A priority goal should be conversion to a T+3 equity settlement } \\
\text { cycle. While the JSE role as guarantor of all trading appears to } \\
\text { be effective, legal action to establish a central counterparty } \\
\text { system warrants careful consideration as it represents the } \\
\text { consensus international best practice. }\end{array}$ \\
\hline
\end{tabular}

\section{F. Authorities' Response to the Assessment}

26. National Treasury welcomes the report and the recommendations of the assessment team on compliance with IOSCO principles. We aim to take these recommendations into account when determining the direction of future reform efforts in this area.

27. South Africa was given 16 "Fully Implemented (FI)", 11 "Broadly Implemented (BI)," and 2 "Partly Implemented (PI)" ratings. We, however, support the Financial Services Board (FSB) in its view that some of the ratings given are too low because the 
explanation of these ratings took factors like hedge fund and OTC derivative regulation into account, which are not mentioned in the corresponding principles. Moreover, in certain instances the ratings are applied inconsistently. Principles achieving a rating below FI may not have been supported by recommendations for improvement while in other cases a rating of FI is awarded even though the assessor appears not fully satisfied and indicates areas for improvement.

\section{Principles 8, 27 and 29}

28. We note that the assessment of Principle 8 has been changed from a "BI" to a "FI" due to the fact that a jurisdiction can't be penalized for the lack of regulation of the OTC market, as this is not required under the IOSCO principles. However, it appears as if a rating of "BI" has been given under Principles 27 and 29, both as a result of the nonregulation of the OTC markets. Although Principles 27 and 29 are rated as "BI", no recommended action plan is provided in Table 2 on page 16 of the report. We, therefore, propose that the ratings of Principles 27 and 29 should be an "FI". Notwithstanding the above, the FSB is committed to the regulation of certain OTC derivatives and has initiated an investigation in this regard.

\section{Principle 18}

29. Principle 18 of IOSCO does not require that hedge funds be regulated. We therefore propose that the rating for Principle 18 should change to "FI". Notwithstanding the above, the FSB is committed to the regulation of hedge funds and has initiated an investigation in this regard. 


\section{Detailed ASSESSMENT}

\section{Table 3. South Africa: Detailed Assessment of Implementation of the IOSCO Principles}

\begin{tabular}{|c|c|}
\hline \multicolumn{2}{|r|}{ Principles Relating to the Regulator } \\
\hline Principle 1. & The responsibilities of the regulator should be clear and objectively stated. \\
\hline Description & 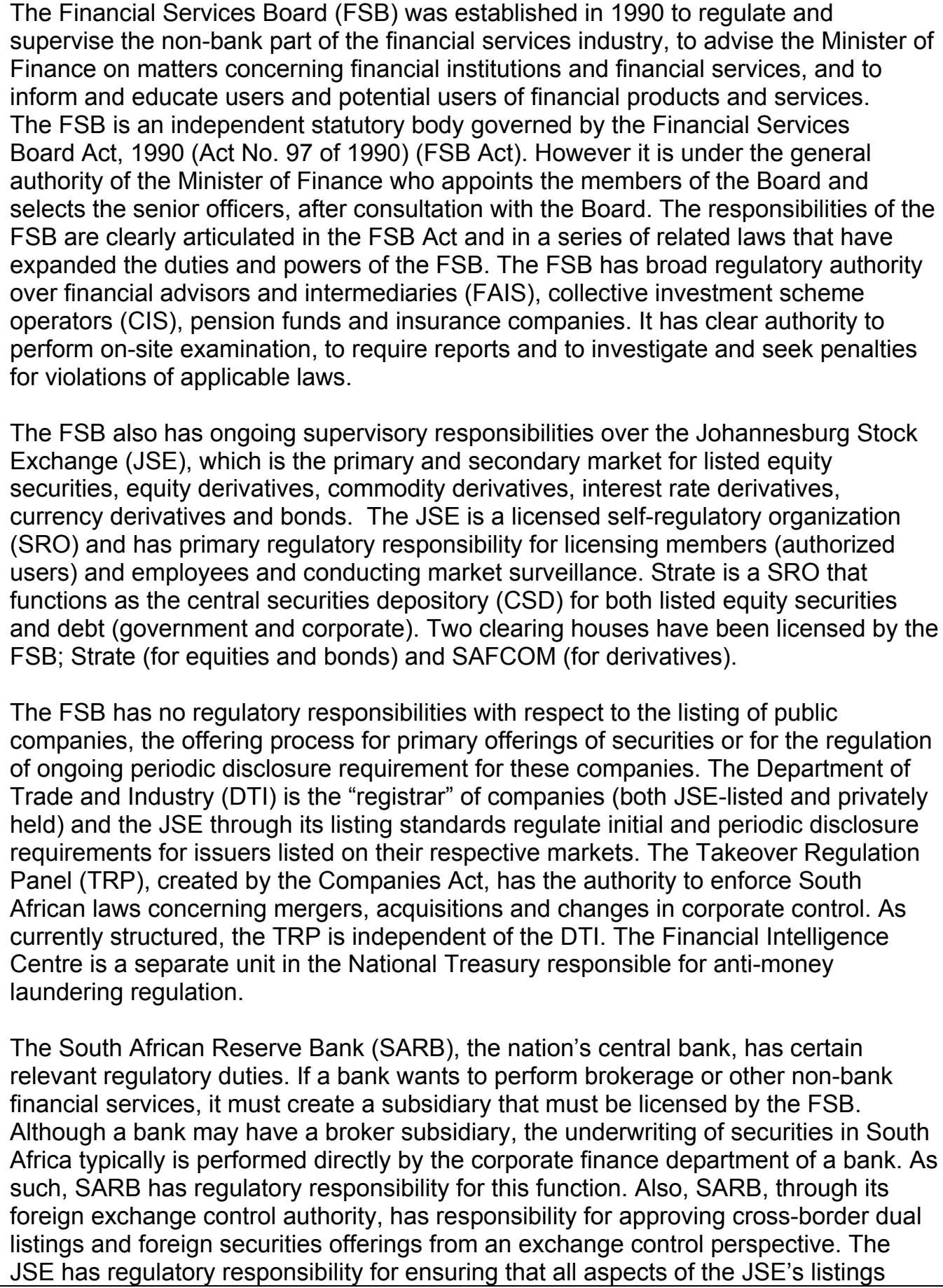 \\
\hline
\end{tabular}




\begin{tabular}{|c|c|}
\hline & $\begin{array}{l}\text { requirements are complied with in this regard. SARB also plays a role in reviewing } \\
\text { offering documents for debt securitizations originated by a bank. } \\
\text { SRO's are critical components of the regulatory system. The FAIS Act exempts firms } \\
\text { and employees that are licensed by the JSE from licensing by the FSB for those } \\
\text { activities regulated by the JSE. Regulation of CIS marketing and disclosure } \\
\text { information to investors was delegated by the FSB to the Association of Collective } \\
\text { Investments (ACI), a voluntary industry organization that declined to apply and be } \\
\text { licensed as an SRO. As a condition of registration the FSB required CIS registrants } \\
\text { that are not members of the ACI to agree to be bound by ACI guidelines. In 2009, ACI } \\
\text { merged with the Association for Savings and Investment in South Africa (ASISA). It } \\
\text { has not been determined whether ASISA will continue to perform the industry } \\
\text { regulatory functions of ACl. } \\
\text { The South African regulatory scheme also includes ten statutory advisory boards and } \\
\text { four standing committees that provide input to the Minister of Finance, DTI, SARB or } \\
\text { FSB on strategic and policy objectives. These include the Policy Board for Financial } \\
\text { Services Regulation, the Financial Markets Advisory Board, the Collective Investment } \\
\text { Scheme Advisory Committee, the Advisory Committee on Financial Services } \\
\text { Providers, and several other committees concerned with other segments of the } \\
\text { financial services sector, but not pertinent to the areas covered by the IOSCO } \\
\text { principles. Also a Standing Advisory Committee on Company Law advises the Minister } \\
\text { of Trade and Industry on company law matters. } \\
\text { In } 2007 \text { the Corporate Laws Amendments Act established a Financial Reporting } \\
\text { Standards Committee, to serve as the accounting standard setting body in South } \\
\text { Africa and a Financial Reporting Investigation Panel to investigate non-compliance } \\
\text { with financial reporting standards. Neither of these entities was ever created and in } \\
2009 \text { the Company Act was amended again. It created a Financial Reporting } \\
\text { Standards Council to supercede the Financial Reporting Standards Committee. The } \\
\text { Financial Reporting Investigation Panel was eliminated, with its functions assigned to } \\
\text { a revamped Company and Intellectual Property Commission (CIPRO). }\end{array}$ \\
\hline Assessment & Fully Implemented \\
\hline Comments & $\begin{array}{l}\text { The South African system of financial services regulation is complex, involving } \\
\text { multiple government agencies, several advisory or oversight committees, and several } \\
\text { self-regulatory organizations. As will be discussed, the role of the self-regulatory } \\
\text { organizations is particularly important in the performance of critical regulatory } \\
\text { functions. While all areas of responsibility appear to be covered, there may be gaps in } \\
\text { the implementation of duties, which will be discussed under the relevant substantive } \\
\text { principles. }\end{array}$ \\
\hline Principle 2. & $\begin{array}{l}\text { The regulator should be operationally independent and accountable in the exercise of } \\
\text { its functions and powers. }\end{array}$ \\
\hline Description & $\begin{array}{l}\text { The FSB is headed by a non-executive Board composed of a chairperson and } \\
\text { members. Members are appointed for staggered three-year terms by the Minister of } \\
\text { Finance. Board members serve at the pleasure of the Minister and can be terminated } \\
\text { at his discretion. The Board meets quarterly to oversee the internal operations and } \\
\text { governance of the FSB. Subcommittees, typically chaired by one Board member and } \\
\text { including FSB senior staff and non-Board members, provide more direct oversight of } \\
\text { core FSB functions, such as licensing (Registrars), legislation (including FSB } \\
\text { regulations) and enforcement. } \\
\text { Executive management of the FSB resides with the Executive Officer (EO) and an } \\
\text { Executive Committee comprised of FSB senior management. The EO has full }\end{array}$ \\
\hline
\end{tabular}


authority to manage the FSB and to make all day-to-day regulatory decisions. Typically the EO, or a Deputy EO, presents proposed decisions to the relevant subcommittee for consultation prior to taking a decision. This, however, is a discretionary not mandatory consultation. The EO and other senior officials are appointed by the Minister, after consultation with the FSB Board.

The Minister has discretionary authority to remove these officials, presumably after consultation with the FSB Board. Grounds for a removal action are not specified in the FSB Act. The Minister of Finance must review all proposed regulations prior to publication in the Official Gazette. The Minister does not review FSB directives, which are binding legal requirements. In practice the FSB relies upon directives to establish regulatory standards. The adoption of regulations, with Minister approval, is limited to matters of broad public policy.

The FSB is self-funded. It has legal authority to impose levies on the various regulated industries and does so annually in consultation with affected industries. In recent years, when surplus funds were collected, the FSB refunded excess levies. In addition to the collection of annual levies the FSB has the authority to seek payment of expenses from individual regulated entities for discrete services performed in the form of fees, e.g., the renewal of exchange licenses. Furthermore, when the FSB conducts an inspection/investigation into regulatory violations, if the violations are proved, the FSB may seek from the appropriate adjudicatory body an order directing payment to the FSB of the costs of the inspection/investigation. The FSB has been successful in obtaining these orders. If violators are ordered to return any profits from a violation or ordered to pay a monetary penalty the FSB places these funds into a segregated account for compensation of victims and to pay for its investor education programs.

FSB staff is subject to an agency Code of Conduct that requires maintenance of confidentiality of information, a prohibition on investment in regulated entities, reporting of securities transactions by the employee and the immediate family. South African law provides immunity for government officials in the non-negligent performance of official duties.

FSB transparency is achieved in several ways. As previously explained, all regulations must be published in the Official Gazette prior to finalization. They are also posted on the FSB website. The agency also prepares a detailed Annual Report to Parliament, which provides a full description of FSB activities, as well as an audited financial statement, overseen by the Board's audit committee. Within the FSB, its Board reviews the staff's strategic objectives and departmental business plans. An Executive Committee, composed of senior FSB staff and separate from the FSB Board, meets bi-weekly to monitor the fulfillment of the annual business plan. The internal operations of the FSB have been certified as ISO 9000 compliant.

Licensing, inspection and investigation/enforcement activities are monitored by the Board subcommittees and also, in the case of inspection/enforcement, by a formal Advisory Committee, composed of outside experts. Enforcement actions may be filed as civil suits, or heard by an FSB Enforcement Committee, comprised of outside experts such as retired judges and persons with expertise in the financial markets. Any decision of the Enforcement Committee, as well as any licensing decision by an FSB registrar may be appealed to the Appeal Panel and subsequently to the South African High Court for de novo review. The written decisions of the Enforcement Committee are posted on the FSB internet website.

Assessment $\quad$ Broadly Implemented

Comments $\quad$ The agency has full control over its budget and funding and day-to-day decisionmaking is within its control. While the Minister has review authority over FSB regulations, this is not a significant issue as regulations are only used to adopt broad 
policies. The FSB relies upon its authority to issue directives to adopt regulatory standards and requirements. The authority of the Minister of Finance to terminate the EO or other senior staff at his discretion creates a potential limitation on FSB independence. This could be cured by amending the law to include an objective standard for termination "for good cause shown."

Principle 3. The regulator should have adequate powers, proper resources and the capacity to perform its functions and exercise its powers.

Description $\quad$ The FSB has grown substantially since the IOSCO review in 2000. It has 412 full-time staff compared to approximately 150 in 2001 . This increase can be partially attributed to the expansion of its authority to oversee financial advisors, collective investment schemes and pension programs. In FY 2006 it collected revenue of R 217.2 million and its operating expenses totaled R 196.6 million. It estimated in FY 2007 revenue of R 252 million and expenses of R 203.4 million. The FSB Board has final responsibility to allocate funds within the FSB on the recommendation of the EO.

The FSB has the authority to pay salaries comparable to private financial services industry pay scales. As a result, its staff is compensated at levels higher than government norms. The FSB reports that this has increased its ability to recruit and retain talented staff, although turnover among its on-site compliance review staff is higher than in other units of the FSB. In FY 2006. Staff turnover was 13.9 percent.

The relevant laws establishing FSB legal authority have all been amended since 2000 (except for the Pension Funds Act). For example, in 2000 the Insider Trading Act of 1998 became effective and the FSB received authority to prosecute insider trading violations and to seek repayment of profits plus a penalty of up to three times the profits gained or losses avoided. In 2005 the Securities Services Act expanded the enforcement powers of the FSB and enabled it to impose financial penalties through its administrative process for market manipulation and other market abuse violations. Another amendment in 2009 expanded the jurisdiction of the Enforcement Committee to encompass violations of all laws administered by the FSB. The Financial Advisers and Intermediaries Services Act and the Collective Investment Schemes Control Act (both enacted in 2002) empowered the FSB to license and regulate financial intermediaries and companies offering investment trust products.

The Companies Act of 1973 is the legal standard governing corporate licensing disclosure. The law has been amended several times, most recently in 2007 and 2009. The DTI, not the FSB, is the primary governmental regulator of all corporate disclosure, including publicly held and privately controlled corporations. The 2007 amendments created the Financial Reporting Investigation Panel (FRIP) within DTI to administer and enforce corporate disclosure and a Financial Reporting Standards Committee (Standards Committee) to set national accounting standards. These bodies were never empanelled. In the interim, the 2009 amendments reassigned the FRIP responsibilities to a reorganized CIPRO and the accounting standards duties were assigned to a new Financial Reporting Standards Council (Standards Council). As of March 2010, CIPRO is still in the process of implementing these responsibilities. While the Companies Act establishes a comprehensive legal framework for regulating company disclosure, issues exist in the implementation. These are discussed under principles 10, 14 and 16.

Assessment $\quad$ Broadly Implemented

$\begin{array}{lll}\text { Comments } & \text { While the powers of the FSB have increased substantially since 2000, disclosure }\end{array}$ requirements for companies and national accounting standards are core regulatory responsibility where the FSB has no direct role to play. At the governmental level, this is the responsibility of DTI. However the DTI has not allocated necessary resources to these functions, as demonstrated by the failure to empanel either the FRIP or Standards Committee in 2007, or the successor entities created in 2009. 
The JSE functions as the primary disclosure regulator for listed companies. While this allocation of responsibility may be sufficient at the present time for the review of initial offerings, future development of the South African markets, through development of an OTC market or creation of electronic trading systems that function as exchanges may necessitate reexamination of this regulatory area.

As discussed subsequently, the FSB does not regulate the over the counter market (OTC) for the securities (debt and equity) of public unlisted companies or for trading in unlisted derivatives instruments. The FSB is conducting a study in 2010 of OTC trading. Based upon the results of this study, the FSB may require additional legal authority to implement recommendations for additional regulation.

Principle 4. The regulator should adopt clear and consistent regulatory processes.

Description $\quad$ Development of FSB directives (functional equivalent of regulations in other jurisdictions) incorporates public input at several steps. All proposed directives must be reviewed by the Legislative oversight subcommittee of the Board. This subcommittee includes outside experts as well as Board members. The FSB is required to publish its proposed directives and regulations in the government gazette for public notice and comment. Regulations, but not directives must receive authorization from the Minister of Finance prior to publication and adoption. Upon final action all FSB regulations are available on the FSB internet website. The FSB considers the cost of proposed regulation in its assessment of regulatory proposals.

FSB investigations/inspections must be authorized at the Deputy EO level. All FSB investigations relating to potential market abuse are published in a list available on the FSB website. If the matter concerns possible insider trading or market manipulation, the stock in question is identified. If the inspection concerns false or misleading disclosures by a company, the identity of the company is not disclosed.

When the FSB staff completes an investigation (inspection) into possible violations, they prepare a report and provide a copy to the subject of the investigation/inspection for a response. Investigations relating to alleged cases of market abuse are considered by the Directorate of Market Abuse, an FSB committee composed of the FSB EO or Deputy EO as well as representatives from other organizations, such as the JSE and the South African Law Society and selected experts in financial markets. The Directorate must by majority vote authorize the staff to commence civil litigation in court, or file the matter with the Enforcement Committee. This committee is chaired by a retired judge and includes other persons with requisite expertise to adjudicate the action. The written decision of the Enforcement Committee must contain a full explanation of the allegations and the rationale for the decision. It is posted on the FSB website. Defendants may appeal the decision to the South African High Court.

Licensing of financial advisors and intermediaries as well as registration of collective investment scheme managers is a major responsibility of the FSB. The decision to approve or reject an application has been delegated to the appropriate Deputy Executive Officer. While the Deputy EO has the legal authority to take final action, typically the proposed action is submitted to the Licensing subcommittee of the FSB Board for review and consultation. This subcommittee is chaired by a Board member and its membership includes experts from outside the FSB.

The FSB Consumer Education Office has undertaken several programs. In conjunction with the Department of Education it is developing a program for teachers on integrating financial consumer education into formal education. It has published an updated booklet on the activities of the FSB. The JSE reports that it has an extensive program of investor education. 


\begin{tabular}{|c|c|}
\hline Assessment & Fully Implemented \\
\hline Comments & $\begin{array}{l}\text { The FSB has developed clear internal procedures for the performance of all functions. } \\
\text { The Executive Committee appears to play a strong oversight role over its staff. The } \\
\text { use of advisory committees, chaired by a Board member, to review and advise on } \\
\text { staff decisions appears to be an effective method of ensuring that authority is properly } \\
\text { used. } \\
\text { The FSB now posts the written decisions of its Enforcement Committee on its website. } \\
\text { These decisions are clear, and demonstrate the effectiveness of the process, the } \\
\text { severity of the potential penalties and provide clear guidance to the financial services } \\
\text { industry on improper conduct and its consequences. }\end{array}$ \\
\hline Principle 5. & $\begin{array}{l}\text { The staff of the regulator should observe the highest professional standards including } \\
\text { appropriate standards of confidentiality. }\end{array}$ \\
\hline Description & $\begin{array}{l}\text { The FSB Code of Conduct establishes a required standard of professionalism. It } \\
\text { contains a prohibition on disclosure or personal use of confidential information, } \\
\text { prohibits staff from owning shares or having an interest in any entity regulated by the } \\
\text { FSB, and requires notification of a supervisor in the event that there is an appearance } \\
\text { of a conflict of interest. Annually, employees must provide a written report on outside } \\
\text { business interests or any business interests by a spouse in any institution regulated } \\
\text { by the FSB. Employees must also disclose any gifts received that are valued at or } \\
\text { exceed R } 350 \text {. The FSB staff report that staff are also required to disclose all } \\
\text { purchases of securities by the employee or the immediate family. This requirement is } \\
\text { not contained in the Code of Conduct. } \\
\text { FSB staff indicated that there is an internal audit function with the authority to } \\
\text { investigate allegations of staff misconduct. However this program was not identified in } \\
\text { the FSB annual report. }\end{array}$ \\
\hline Assessment & Fully Implemented \\
\hline Comments & $\begin{array}{l}\text { The FSB policy on reporting of employee securities trades should be added to the } \\
\text { Code of Conduct. At a minimum, it should require prompt ongoing disclosure of all } \\
\text { purchases and sales by employees and their immediate families. An effective } \\
\text { disclosure system should also include some method of periodically monitoring } \\
\text { employee compliance by reviewing personal investment accounts. } \\
\text { While the Code requires employees to disclose the receipt of any gifts valued at R } 350 \\
\text { or more, consideration should be given to limiting gifts from regulated entities or } \\
\text { agents or representatives in excess of some amount. } \\
\text { Given the routine departure of FSB staff to work for regulated entities, the FSB should } \\
\text { consider adopting a policy requiring employees to notify a supervisor that they are } \\
\text { negotiating possible employment with a regulated entity. The FSB might also consider } \\
\text { a "cooling off" period during which former staff would not be permitted to appear } \\
\text { before the FSB or work on matters relevant to specific matters on which they worked } \\
\text { while at the FSB. Restrictions such as this could be included in employment contracts. } \\
\text { The FSB reports that its Human Resources Office has circulated to FSB staff a } \\
\text { proposal to address these issues. } \\
\text { If the FSB has an internal inspector general or auditor with the authority to investigate } \\
\text { allegations of staff misconduct, its activities should be disclosed in the annual report. If } \\
\text { this function has not been formally established, the FSB should create one. } \\
\text { In its annual report, the FSB includes a full financial statement, independently audited } \\
\text { by the Auditor General of South Africa. An attachment indicates that the FSB has } \\
\text { invested a portion of its excess funds in a broad range of assets, including shares in } \\
\text { companies listed on the JSE. The attachment states that the funds are invested by an }\end{array}$ \\
\hline
\end{tabular}


independent investment manager who has full discretion over investments. While this does not appear to be inappropriate (and is similar to employee pension funds created in other countries), it does create a potential for the appearance of a conflict of interest, in the event that the FSB must investigate trading or false disclosures concerning a company in which it is a shareholder. The FSB must be mindful of the potential for adverse publicity and ensure that it has clear separations of functions in the management of these funds, in the process for selecting the independent manager and in the decisions to buy or sell securities.

\section{Principles of Self-Regulation}

Principle 6. The regulatory regime should make appropriate use of Self-Regulatory Organizations (SROs) that exercise some direct oversight responsibility for their respective areas of competence, and to the extent appropriate to the size and complexity of the markets.

Description $\quad$ The South African system of capital market regulation depends heavily upon several self-regulatory organizations to act as the primary, and in some cases, the sole regulatory entity. The JSE is a demutualized exchange and its own stock is listed for trading on the JSE. Any holding in excess of 15 percent of JSE stock must be approved by the FSB. The JSE has statutory recognition as an SRO. It is the sole regulator of listed company disclosure compliance (the FSB performs this role for JSE shares). It also is the sole licensor of stockbrokers (authorized users) and their employees. The JSE is responsible for business conduct and capital adequacy regulation of member firms and most derivative members. The JSE also has primary responsibility for ongoing market surveillance (except for trading in its own shares, which is the responsibility of FSB), with the FSB responsible for investigation and enforcement of market abuse violations. The JSE retains enforcement authority over its members and their employees for violations of its rules. SAFCOM, a wholly-owned subsidiary of the JSE, functions as the de facto central counterparty (technically as guarantor of settlement) and clears derivative transactions conducted on the JSE's derivatives markets. Strate is the central securities depository for both markets. Strate is jointly owned by the JSE (44.6 percent) and the four largest South African banks each owning 12-15 percent. Citibank owns a small interest (0.1 percent). Strate also provides clearance and settlement services for debt trading (bilaterally settled) and has been licensed by the FSB as a clearinghouse. The licenses of the SROs and clearing houses are annually renewed by the FSB.

The Association of Collective Investments (ACI) was until 2009 a voluntary industry organization which the FSB delegated authority to for the creation of codes of business conduct for its members and responsibility to review all marketing information and investor disclosure documents used by its members. The FSB required non-member $\mathrm{CIS}$ companies to adhere to $\mathrm{ACl}$ standards as a condition of the registration granted by the FSB. While CISCA provides for the creation of a formal $\mathrm{SRO}, \mathrm{ACl}$ chose to remain a voluntary member-based organization. In 2009, ACl merged into a new industry organization the Association for Savings and Investment in South Africa (ASISA). ASISA represents CIS, and other investment firms such as insurers and pension providers. While ASISA has adopted the codes of conduct developed by $\mathrm{ACl}$, which set industry standards for marketing and disclosure, it has determined to function as an industry representation organization and not function as an unofficial SRO.

Assessment No Rating to be assigned

Comments

The 2008 assessment update identified a number of problems arising from the $\mathrm{ACl}$ performing SRO functions without registering as an SRO. It recommended that the $\mathrm{ACl}$ choose to become either an industry trade group or a formal SRO. The ASISA, as the successor to $\mathrm{ACl}$, has decided that it will be an industry representative group and substantially reduce the self-regulatory functions that it performs. While this will increase the burden on the FSB to perform these duties, that is preferable to the previous ambiguous and unofficial status of the ACl. 
In 2009 the FSB gained the authority to take action against a CIS via the Enforcement

Committee. The ability of the FSB to bring administrative enforcement actions for violations of CISCA substantially reduces the need for ASISA to have a disciplinary program for its membership.

Principle 7. SROs should be subject to the oversight of the regulator and should observe standards of fairness and confidentiality when exercising powers and delegated responsibilities.

Description $\quad$ The FSB must approve all new or amended SRO rules after those have been published in the Government Gazette for comment for a period of two weeks. The exchanges have been requested in writing to submit all proposed new products to the FSB for in-principle approval. One gap is in the area of exchange listing requirements, where the FSB does not have the authority to review and approve listing requirements but has consultative authority only. A proposed amendment to the Securities Services Act would eliminate this gap. The FSB does have the authority to enforce the requirements adopted and its staff participates in JSE listing committee meetings.

The FSB has other methods for exercising regulatory oversight. All SRO's must apply for license renewal annually. As part of the renewal process, the FSB schedules onsite examinations of SRO's, to be completed prior to the licensing decision. Finally the FSB believes that it would be possible to impose money penalties against an SRO for a violation of the Securities Services Act.

\begin{tabular}{ll}
\hline Assessment & Broadly Implemented \\
\hline Comments & $\begin{array}{l}\text { Because JSE listing requirements effectively control disclosure responsibilities of } \\
\text { listed companies, it is essential that they are subject to governmental regulatory } \\
\text { oversight. The FSB has indicated that action by Parliament on the proposed } \\
\text { amendment to the SSA to provide the FSB with legal authority to review and approve } \\
\text { JSE listing requirements is a priority. }\end{array}$
\end{tabular}

In 2008, the status of $\mathrm{ACl}$ as an unregistered SRO was identified. The consolidation of $\mathrm{ACl}$ into ASISA and that organization's decision to focus on being an industry organization rather than adopt the $\mathrm{ACI}$ role of informal and unregulated SRO, substantially reduces the concerns expressed in the 2008 assessment update. However, continued reliance by the industry on the $\mathrm{ACl}$ marketing and disclosure standards for CIS and on ASISA to monitor industry compliance would negatively affect the assessment of this principle.

\section{Principles for the Enforcement of Securities Regulation}

Principle 8. $\quad$ The regulator should have comprehensive inspection, investigation and surveillance powers.

Description $\quad$ INSPECTIONS - The Inspections of Financial Institutions Act of 1998 (IFIA), the Financial Advisors and Intermediary Services Act of 2002 (FAIS), the Collective Investment Schemes Control Act of 2002 (CISCA), and the Securities Services Act of 2004 collectively empower the FSB to conduct periodic inspections (compliance reviews) of registered financial advisors and intermediaries and collective investment scheme managers. Stockbrokers licensed by the JSE are subject to JSE inspection and are exempt from FAIS unless they engage in financial services that are outside the regulatory ambit of the JSE. Then they must also register with the FSB under FAIS.

The FSB has the authority to conduct unannounced on-site visits under FAIS (as of November 2008). These on-site visits supplement the FSB review of the annual audited financial statements and the self-assessment compliance reports that registrants are required to submit in conjunction with its program for on-site inspections. In 2006 the FSB began implementation of a "risk-based" system for selecting registrants for on-site inspection. The FAIS risk model is largely based upon 


\begin{tabular}{|c|c|}
\hline & 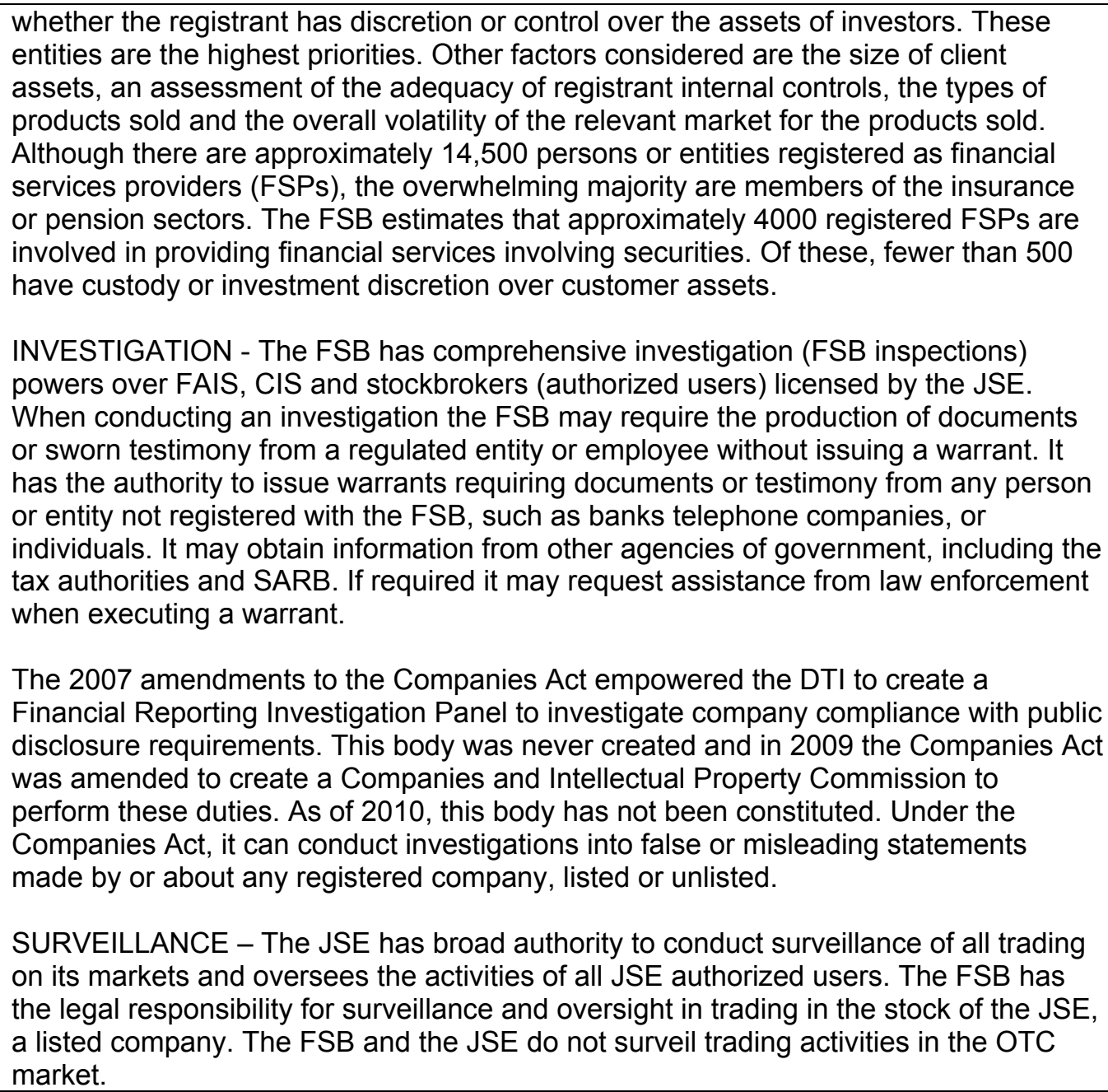 \\
\hline Assessment & Fully Implemented \\
\hline Comments & $\begin{array}{l}\text { This principle is expressly limited to regulated markets and regulated intermediaries. } \\
\text { While the OTC market is not a regulated market, and not included in the assessment } \\
\text { of this principle, the lack of oversight should be noted, because regulated } \\
\text { intermediaries are important participants and because of the influence of this market } \\
\text { on the regulated market for single stock futures. } \\
\text { The FSB is seeking a legislative amendment that would expand its authority and } \\
\text { enable it to conduct on-site visits to external compliance officers. A significant number } \\
\text { of FAIS registrants rely upon third party firms to perform required compliance duties. } \\
\text { As an effective regulatory program should periodically examine the adequacy of firm } \\
\text { compliance processes this would be an essential augmentation of its authority. } \\
\text { The } 2009 \text { amendments to the Companies Act provide CIPRO with broad investigative } \\
\text { authority over all public companies. As discussed in principle 10, it is too soon to tell } \\
\text { how, or if, this authority will be implemented. }\end{array}$ \\
\hline Principle 9. & The regulator should have comprehensive enforcement powers. \\
\hline Description & $\begin{array}{l}\text { The enforcement authority of the FSB has been greatly expanded since the } 2000 \\
\text { assessment. In } 1999 \text { the Insider Trading Act became effective. It provided the FSB } \\
\text { authority to obtain orders compelling violators to give back illegal profits and to pay a } \\
\text { penalty of up to three times the amount of the profits or the losses avoided. The } \\
\text { Insider Trading Act has been replaced by the Securities Services Act. }\end{array}$ \\
\hline
\end{tabular}


The Securities Services Act of 2004 (SSA) further expanded FSB authority to include the ability to obtain the same penalties for market manipulation, market abuse and false or misleading statements concerning listed companies. In 2009, the Financial Institution (Protection of Funds) Act was amended to expand FSB authority to bring actions before its Enforcement Committee for violations of all acts within its jurisdiction. Because the Enforcement Committee has proven to be speedy and effective, it has become the preferred avenue for taking action; reducing the use of civil litigation or referral of matters to the public prosecutor for criminal action.

When the FSB staff complete an investigation (inspection) into possible violations, they prepare a report and provide a copy to the subject of the investigation/inspection for a response. All proposed enforcement actions concerning market abuse must then be reviewed by the Directorate of Market Abuse, a committee chaired by the FSB EO with representatives of other organizations, such as the JSE and the South African Law Society. The Directorate must by majority vote authorize the staff to commence civil litigation in court, or file the matter with the Enforcement Committee.

The Enforcement Committee is chaired by a retired judge and includes other persons with requisite expertise to adjudicate the action. The written decision of the Committee must contain a full explanation of the allegations and the rationale for the underlying decision. It is posted on the FSB website. Defendants may appeal the decision to the South African High Court. Since its creation the Enforcement Committee has issued 27 written opinions. In November 2008, the jurisdiction of the Enforcement Committee was substantially expanded. The FSB may now bring actions for a violation of any of the laws it administers.

The JSE has enforcement authority over its members and the issuers of listed securities. The JSE may suspend trading in a stock for up to 30 days, which may be extended for an additional 30 days. ASISA and IRBA have disciplinary programs to enforce compliance by their membership with the law and association codes of conduct. Violations may also be brought by the FSB. The Takeover Regulation Panel is an independent body with the authority to enforce South African laws concerning mergers, acquisitions and changes in corporate control. Section 20 of the Securities Services Act of 2004 provides the FSB with the authority to adopt regulations or proscribe conduct in the OTC market. Section 76 of the SSA provides the FSB with the authority to bring an enforcement action for market misconduct or false statements concerning any public company, whether listed or unlisted. To date, the FSB has determined as a matter of policy to concentrate its resources on the listed securities market.

The CIPRO has broad powers to enforce the Companies Act disclosure requirements. It can bring civil law suits to impose money penalties and it can refer its investigation findings for criminal prosecution. The law provides sanctions of up to R50 million fine and or a maximum of ten years imprisonment. Disciplinary actions may be heard by a Companies Tribunal. Neither body has been formally empanelled, as of March 2010. In the past year, the FSB has used its broad power to sanction JSE-listed companies found to have made public misstatements.

Assessment $\quad$ Fully Implemented

Comments $\quad$ The FSB has made significant progress in building its enforcement program since the 2000 FSAP assessment and 2008 FSAP update. The Enforcement Committee has become an effective forum to take prompt action. The 2009 Parliamentary action expanding the jurisdiction of the Enforcement Committee to include all FSB administered laws provided the FSB with an effective vehicle for enforcing compliance. The 2009 amendments to the Companies Act provides CIPRO with comparable powers and the Companies Tribunal is modeled after the FSB 


\begin{tabular}{|c|c|}
\hline & $\begin{array}{l}\text { Enforcement Committee. Empanelling the Tribunal and providing CIPRO with the } \\
\text { resources to enforce the Companies Act should be a priority for DTI. }\end{array}$ \\
\hline $\begin{array}{l}\text { Principle } \\
10 .\end{array}$ & $\begin{array}{l}\text { The regulatory system should ensure an effective and credible use of inspection, } \\
\text { investigation, surveillance and enforcement powers and implementation of an effective } \\
\text { compliance program. }\end{array}$ \\
\hline Description & 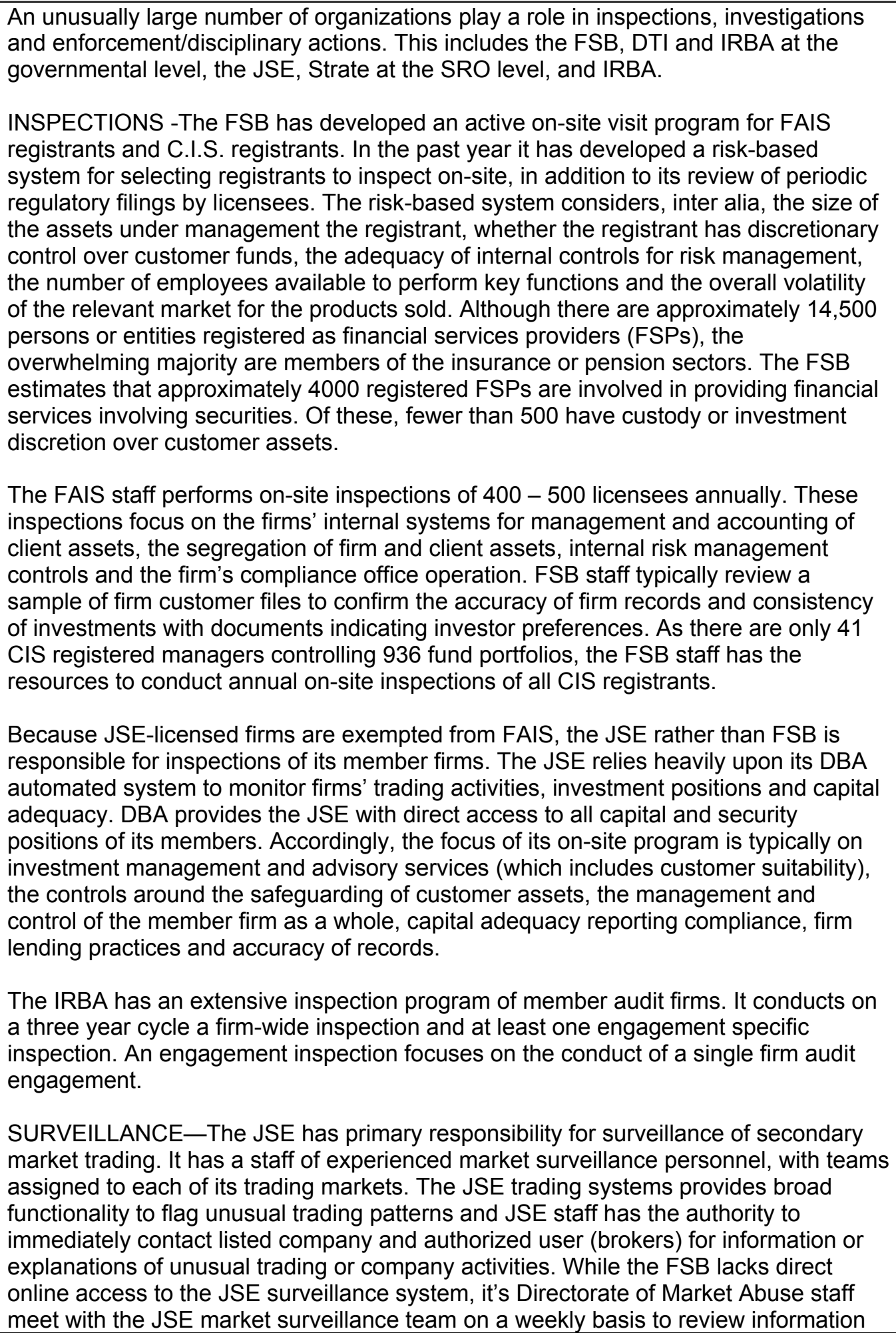 \\
\hline
\end{tabular}


compiled by the JSE and is able to request any needed information from the JSE. The FSB retains exclusive responsibility to monitor trading in the listed stock of the JSE. An experienced FSB employee personally monitors this trading.

While the FSB appears to possess sufficient authority to oversee the OTC market, including the surveillance function it has exercised its discretion to forbear assuming a regulatory role. It is acknowledged that there is a strong OTC market in non-standard derivatives instruments. These include contracts for difference (CFD), a derivative instrument tied to equity securities and functionally similar to single stock futures. Surveillance of OTC trading in CFD's is limited. The JSE can monitor some CFD activity when a member firm hedges its CFD exposure with an offsetting trade in a single stock future. Also, the JSE collects information on the level of activity in OTC derivatives by its equities member firms through its capital adequacy systems.

Also, there is no surveillance of the OTC market in securities issued by unlisted companies. Because they are unlisted, the JSE has no legal authority. At the governmental level this appears to be the responsibility of the DTI not the FSB. As this is an entirely opaque sector, it is not possible to estimate the size of the market (it may be very small) or its significance as a regulatory problem.

Because of the lack of available information on the size or activity of the OTC market, it is difficult to assess its significance. In the 2008 assessment update, it was noted in the comments that anecdotal information suggested that there might be sufficient activity to warrant the FSB taking a greater role. Accordingly the 2008 update encouraged the FSB to review the appropriateness of this regulatory strategy. In 2008, a customer default on a large CFD position precipitated a default by a broker in a listed single stock futures position that the broker had purchased as a hedge against the client's CFD position. Fortunately the clearing member for the defaulting broker was sufficiently well capitalized and absorbed the loss so no systemic problems resulted. Following its review of the events, and consistent with the recommendations of international financial organizations such as the G-20 and the Financial Stability Board, the FSB determined to commission a study of the OTC derivatives market. This study has begun and should be completed within a year.

INVESTIGATION/ENFORCEMENT - During the past six years, the FSB has significantly expanded its investigation and enforcement program and appears to have built a strong resume of successful actions. The FSB reports that it has obtained judgments imposing R 48 million. Since obtaining the authority in 2004 to take action against insider trading, the FSB has successfully filed 30 insider-trading cases.

Two discrete offices of the FSB have investigation authority. The Directorate of Market Abuse conducts investigation concerning insider trading, market misconduct and company misstatements by JSE companies. The Inspectorate Office is the primary FSB investigative unit. It has responsibility for investigations concerning insurance companies, pension funds, CIS and FAIS and the SSA. The office has a staff of 16 including 4 accountants, 4 lawyers (2 advocates, 2 attorneys) and 3 investigators. It has the ability to outsource investigations to private law firms and accountancies if required. This office has broad investigative authority under the IFI Act.

The FSB has its own market abuse team of 5 professionals. This unit is responsible for investigations of violations involving trading in listed companies on the JSE. This includes insider trading, market manipulation and false or misleading statements concerning listed companies. The office relies heavily upon JSE market surveillance for information on unusual trading on the JSE's markets, which the JSE is able to provide given its extensive real time surveillance tools. 
The JSE has the authority to fine or revoke the licenses of its members or their employees. If a matter concerns possible market abuse violations (including insider trading or market manipulation), after it has made a preliminary inquiry, the JSE will refer the matter to the FSB for further investigation. If the misconduct concerns a violation of JSE rules or listing standards, It may take disciplinary action on the basis of its inquiry.

The ASISA and IRBA have the authority to investigate and impose penalties on members but not persons employed by members. The ASISA does not make its action public and the IRBA announces its actions without disclosing the identity of the party disciplined.

Under the 2009 amendments to the Companies Act, CIPRO has responsibility for enforcing corporate (both public and private company) compliance with all disclosure requirements. Enforcement proceedings concerning violations may be heard by the Companies Tribunal, which has powers substantially similar to the FSB Enforcement Committee. As of March 2010, CIPRO had not established a unit to enforce the Companies Act and the Companies Tribunal had not yet been empanelled. While the FSB does not have direct authority to enforce compliance the Companies Act by listed companies, it does have general authority to take action against a listed company for material misstatements in documents filed with the JSE. It has increasingly used this authority. Recent actions have included an action against a listed company and its CEO for financial reporting fraud that resulted in a penalty against the company of $R 1$ million and a penalty for the CEO of R 1 million.

Assessment 1 Fully Implemented

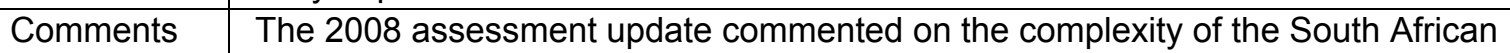
regulatory system, involving so many entities, and concluded that it creates the potential for inconsistency in application of authority and effectiveness of the process. The 2008 assessment highlighted the limited role played by the DTI, and its failure to implement the Company Act amendments mandate to create a Disclosure Reporting Investigation Panel and the lack of attention paid to the OTC market and the prelisting IPO process.

In 2010, the system continues to be complex, involving the FSB, DTI, JSE and IRBA. However the continued development and expansion of the FSB investigation and enforcement program, building upon the expanded jurisdiction of the Enforcement Committee, has substantially lowered the level of concern in this assessment. Because the FSB may now take action for any violation of its laws and has demonstrated a capacity and commitment to do so, it is less worrisome that many other entities have responsibilities that may not be fulfilled.

As in 2008, the lack of a credible program by CIPRO to enforce the Companies Act continues to be a significant problem. As noted previously, the DTI Disclosure Reporting Investigation Panel was never established and, under the 2009 amendments, it has been supplanted by CIPRO. However, as of March 2010, CIPRO has not begun implementing its authority and the Companies Tribunal has not been empanelled. Historically, the DTI has focused its resources on the registrar function. Until CIPRO becomes fully operational and demonstrates that it is a credible enforcer of the Companies Act, it is not clear whether this responsibility is adequately performed. For this reason possible legislative action to transfer authority from CIPRO to the FSB should be carefully considered.

The FSB has made substantial progress in building its on-site examination program. The use of a risk-based system to identify which registrants to visit is sound. However a successful program requires routinely assessing whether the risk parameters 
chosen are in fact appropriate. While the amount of customer money managed or held by a firm must always be an important risk criterion, it may not be a criterion that most closely correlates with misconduct. Other criteria, such as the adequacy of internal control procedures, reliance upon third party compliance personnel or the variety and complexity of investment products offered may be useful factors to consider. All of these appear to be considered by the FSB in some form. The proper weighting of them, however, requires careful self-examination of the results of its visits from a program-wide perspective. A successful program also requires well-trained and knowledgeable staff possessing the expertise and the ability to understand industry practices and identify questionable practices. Hiring, training and retaining expert staff is a challenge for all capital markets regulators. The FSB should consider ways of augmenting the capabilities of its staff by recruiting people with industry experience and working with the industry to provide ongoing training, through exchange programs and secundments.

The JSE market surveillance program appears to operate effectively and the working relationship with FSB staff appears to be strong. A review of sample weekly surveillance reports submitted to the FSB evidenced strong understanding of the surveillance function. Recent FSB enforcement actions based upon market abuse indicate effective surveillance. While the JSE systems appear to be effective, they are old technology. The JSE has publicly committed itself to completely upgrading and modernizing its core I.T. systems. This effort has been underway for several years. The JSE should be encouraged to make every effort to successful complete the system replacement project (SRP). The JSE has publicly made this commitment.

As described previously, OTC trading in non-standard derivatives products, based on underlying listed securities remains an area of uncertainty and the FSB has announced that a study of OTC derivatives trading will be conducted in 2010 . The FSB is to be commended for taking a proactive approach. While OTC derivatives trading should clearly be the highest priority of this study, as it is clearly an active market with known risks, the FSB should not exclude other components of the OTC market from this inquiry. Because the size and activity in other parts of the OTC market is largely unknown, the FSB is strongly encouraged to study other aspects of the South African OTC market, including secondary market trading in the stock and debt of unlisted, public companies. A complete understanding of the size of the OTC market will provide the FSB with the information needed to determine whether any changes in regulatory policy and scope are appropriate.

If additional surveillance and regulation of the OTC market is required, the legal limitations on the authority of the JSE may require the FSB to assume greater direct responsibility for the OTC market. The degree of regulation required is of course impossible to estimate without greater understanding of the market, the sophistication of the participants, the range and characteristics of the products traded and the problems, if any, that exist. The level of regulation may be "light" or it may be "heavy", based upon a proper assessment of the market.

Regarding the OTC market, responsibility for monitoring and investigating possible misconduct in the pre-listing IPO process is another concern. The JSE believes that it's regulatory and enforcement authority commences at the point a security is listed on the JSE, excluding the pre-listing IPO process. The FSB has the same view, although it believes that it could use its authority under section 76 of the SSA to enforce compliance with non-listed and pre-listed companies.

The 2008 assessment recommended careful examination of the compliance and disciplinary programs of $\mathrm{ACI}$ (now ASISA). It noted the potential problems that may arise from relying on non-SRO member organizations to perform enforcement 


\begin{tabular}{|c|c|}
\hline & $\begin{array}{l}\text { functions. Because the industry controls their budgets, they may have inadequate } \\
\text { resources to fulfill the responsibility. It was also noted that an industry organization } \\
\text { may have limited enforcement powers (For example in } 2008 \text { the ACI maximum fine } \\
\text { was R } 40,000 \text { and for some lesser violations the maximum was only R } 1,000 \text { ). The } \\
2009 \text { expansion of the Enforcement Committee's jurisdiction substantially reduced the } \\
\text { significance of this problem, as the FSB now may take action rather than depend on } \\
\text { the ASISA, the successor to ACI. Also, ASISA has indicated that it is not likely to } \\
\text { assume the ACI disciplinary function. } \\
\text { IRBA's policy of not publicly disclosing persons or entities committing violations should } \\
\text { be reconsidered. To the extent that IRBA takes disciplinary action, it is important that } \\
\text { these actions be made public. Public notice increases the general deterrent effect of } \\
\text { the disciplinary process and promotes investor confidence. }\end{array}$ \\
\hline \multicolumn{2}{|r|}{ Principles for Cooperation in Regulation } \\
\hline $\begin{array}{l}\text { Principle } \\
11 .\end{array}$ & $\begin{array}{l}\text { The regulator should have authority to share both public and non-public information } \\
\text { with domestic and foreign counterparts. }\end{array}$ \\
\hline Description & $\begin{array}{l}\text { The Financial Services Board Act empowers the FSB to share information, if it is in } \\
\text { the public interest, with other financial regulatory bodies, SRO's and foreign financial } \\
\text { regulators. The Act also empowers the FSB to "render assistance" to these entities. } \\
\text { The Inspection of Financial Institutions Act (§3A) provides the FSB the authority to } \\
\text { conduct inspections of any person pursuant to a request from a domestic or foreign } \\
\text { authority under a memorandum of understanding (MOU) and to share information it } \\
\text { obtains. The FSB states that it has utilized this authority to subpoena witnesses and } \\
\text { compel the production of documents, even when the inquiry concerns potential } \\
\text { violations of foreign law and may not entail a violation of South African law. } \\
\text { The SSA also empowers the JSE to share information with other regulators. } \\
\text { The FSB has the authority to share information without seeking approval from external } \\
\text { authorities. }\end{array}$ \\
\hline Assessment & Fully Implemented \\
\hline Comments & $\begin{array}{l}\text { The FSB has comprehensive authority to obtain and share information with domestic } \\
\text { and foreign counterparts. The FSB is a signatory to the IOSCO multilateral } \\
\text { memorandum of understanding (MLAT). Acceptance as a signatory requires an } \\
\text { independent determination by IOSCO that the regulator has all necessary legal } \\
\text { authority and complies with all relevant principles regarding cooperation and } \\
\text { assistance with other regulatory authorities. }\end{array}$ \\
\hline $\begin{array}{l}\text { Principle } \\
12 .\end{array}$ & $\begin{array}{l}\text { Regulators should establish information sharing mechanisms that set out when and } \\
\text { how they will share both public and non-public information with their domestic and } \\
\text { foreign counterparts. }\end{array}$ \\
\hline Description & $\begin{array}{l}\text { The FSB has a formal MOU with the SARB for the exchange of information and } \\
\text { reports that it has an agreement to share information with the Revenue Authority. } \\
\text { As noted, the FSB has been accepted as a signatory of the IOSCO MLAT. The FSB } \\
\text { has also entered into } 50 \text { bilateral MOUs with foreign regulatory authorities. The FSB } \\
\text { has an internal procedure for requesting and providing information under the MLAT. } \\
\text { All requests must be reviewed and approved and coordinated by a designated staff } \\
\text { person, who is not required to obtain approval from an external authority. }\end{array}$ \\
\hline Assessment & Fully Implemented \\
\hline Comments & $\begin{array}{l}\text { It appears that the FSB has developed an effective internal process for responding to } \\
\text { foreign information requests. }\end{array}$ \\
\hline $\begin{array}{l}\text { Principle } \\
13 .\end{array}$ & $\begin{array}{l}\text { The regulatory system should allow for assistance to be provided to foreign regulators } \\
\text { who need to make inquiries in the discharge of their functions and exercise of their } \\
\text { powers. }\end{array}$ \\
\hline Description & $\begin{array}{l}\text { As noted above, the FSB has clear authority to obtain information from its files or from } \\
\text { third parties, by inspection or compulsory process, information requested by domestic } \\
\text { or foreign regulators pursuant to an MOU. This authority is not limited to matters }\end{array}$ \\
\hline
\end{tabular}




\begin{tabular}{|c|c|}
\hline & $\begin{array}{l}\text { constituting a violation of South African law. As a signatory of the MLAT, the FSB has } \\
\text { agreed to provide information to other signatories when requests are received. }\end{array}$ \\
\hline Assessment & Fully Implemented \\
\hline Comments & $\begin{array}{l}\text { The FSB reported that it has been able to provide assistance to all foreign information } \\
\text { requests that it has received from signatories to the MLAT and from other countries } \\
\text { with which it has similar information sharing arrangements. }\end{array}$ \\
\hline & Principles for Issuers \\
\hline $\begin{array}{l}\text { Principle } \\
14 .\end{array}$ & $\begin{array}{l}\text { There should be full, accurate and timely disclosure of financial results and other } \\
\text { information that is material to investors' decisions. }\end{array}$ \\
\hline Description & 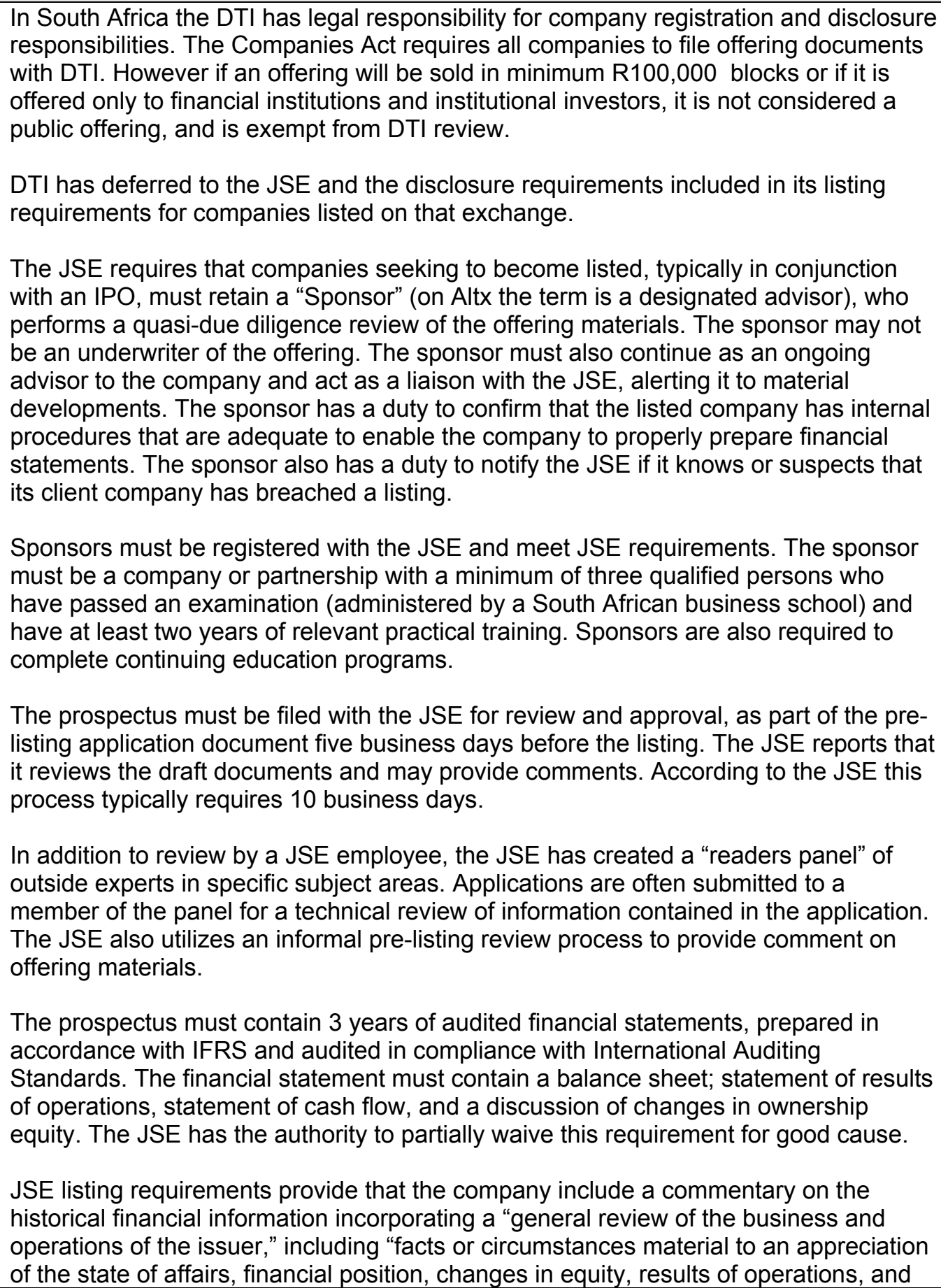 \\
\hline
\end{tabular}


cash flows of the issuer."

Advisors of an offering are free to use any offering materials during the pre-listing process. Road shows are commonly relied upon to solicit investors. There is no regulatory oversight of these aspects of the initial offering process.

The Companies Act requires the offering to be completed within 4 months. The company and its directors are liable for misstatements in a company filing. The JSE and FSB both can impose sanctions. The DTI may conduct an investigation and, if there are violations of the Companies Act, it may refer the matter for criminal prosecution.

The JSE has two sets of listing requirements - one for its main board and one for its small company board, named Alt ${ }^{x}$. The principal differences pertain to requirements for size (minimum share capital for main - R 25 million. For Alt ${ }^{x} 2$ million), free float (20 percent main and 10 percent Alt ${ }^{\mathrm{x}}$ ), number of shareholders (300 on main and 100 on $\mathrm{Alt}^{\mathrm{x}}$, profit history ( 3 years on main with a minimum pre-tax profit of $\mathrm{R} 8$ million, 1 year profitability with no minimum on Alt $\left.{ }^{\mathrm{x}}\right)$. Although no profit history is required on $\mathrm{Alt}^{\mathrm{x}}$, the JSE does regulate forecast information provided by the issuer.

The JSE has several notable additional requirements for Alt $^{x}$ companies. These companies must have a designated advisor (analogous to a main board sponsor), from a list of JSE-approved persons. The company directors must have completed an Alt ${ }^{\mathrm{x}}$ induction training program, and 25 percent of the directors must be non-executive. The company must submit a profit forecast for the remainder of the fiscal year and for the next full fiscal year. Either the company's attorneys or auditors must hold in trust 50 percent of the shareholdings of each director and the designated advisor. Half may be released after the publication of all the forecast information in the prospectus, with the remainder released one year later.

The JSE requires companies to file an annual report, containing audited financial statements within 6 months of the end of its fiscal year, and at least 21 days before a shareholders meeting. If a company doesn't publish its annual report within 3 months of the year-end, it must issue a provisional report within 3 months of the year-end containing reviewed but unaudited or audited financial statements. Companies must also publish an interim report covering the first 6 months of the fiscal year, no later than 3 months after the end of the period. Companies that fail to meet these deadlines are notified by the JSE that if the filing is not made within 30 days, the JSE will suspend trading in the security. There is no requirement for quarterly reports, but companies are permitted to report quarterly on a voluntary basis.

The JSE also requires companies to issue, without delay, a cautionary notice if there are any developments in the issuer's sphere of activity, which may lead to material movements in the price of the issuer's securities. These notices are single sentence statements that do not contain specific information. In addition, the JSE requires companies to issue a Trading Statement when there is a reasonable certainty that it will result in a 20 percent change in the financial statement from the preceding period (companies that voluntarily issue quarterly reports do not have to issue Trading Statements but can include the information in the next quarterly report). Transactions in company assets that are equal to 5-25 percent of company market cap must also be disclosed, including share offerings or buybacks for more than 3 percent of market cap. This information must be announced in summary form over SENS, the Stock Exchange News Service, an electronic system privately operated by the JSE.

Companies must also post required information on the company internet website, and in some cases must publish in the news media. The JSE may grant companies disclosure exemptions for confidential information if the disclosure will prejudice the 


\begin{tabular}{|c|c|}
\hline & 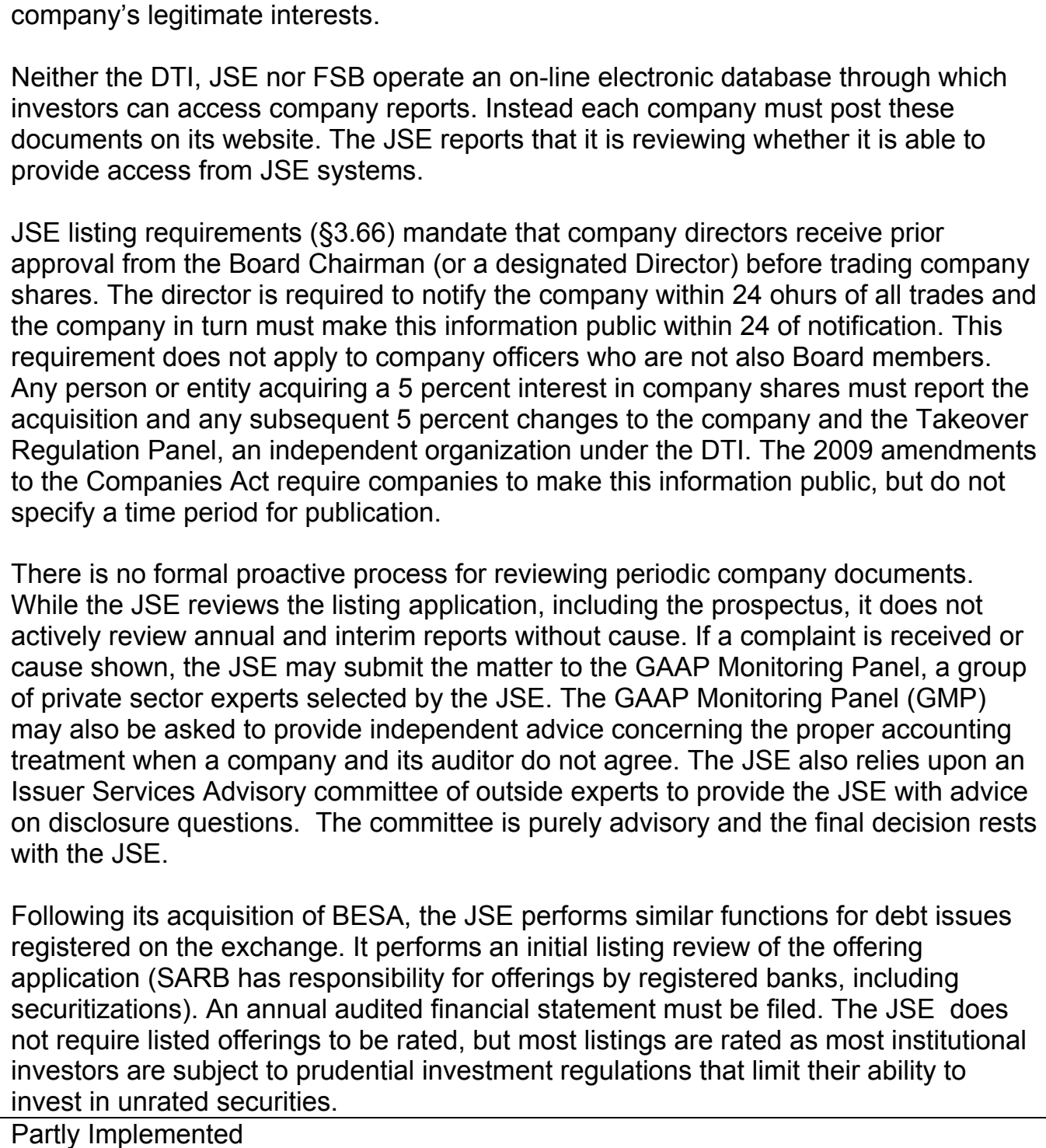 \\
\hline & \\
\hline Comments & $\begin{array}{l}\text { While the JSE appears to have a sound program to review applications for listing, the } \\
\text { accompanying disclosure documents, and circulars concerning special transactions, } \\
\text { its review program for periodic reports, such as annual reports, by listed companies is } \\
\text { limited. The JSE relies upon complaints before submitting periodic disclosure } \\
\text { materials to the GMP for review. The JSE also examines any company restatement } \\
\text { made. The lack of a proactive system for reviewing periodic disclosure reports is a } \\
\text { serious regulatory gap that warrants careful reexamination. } \\
\text { The amount of investment and trading in the secondary market dwarfs the initial } \\
\text { offering process. Timeliness, accuracy and completeness of annual reports by listed } \\
\text { companies and other periodic filings or special announcements are fundamental to a } \\
\text { fair and efficient secondary market. To be effective this requires ongoing proactive } \\
\text { regulatory review of these documents. A sound system of proactive monitoring of } \\
\text { listed company disclosure is critical to keeping markets informed, and there is } \\
\text { currently a large gap in this area. The CIPRO, which will have the authority to review } \\
\text { corporate disclosure statements and to enforce compliance, has not been created by } \\
\text { DTI and it is likely that if and when it is created, it will defer to the JSE on matters }\end{array}$ \\
\hline
\end{tabular}


pertaining to listed companies.

Further progress in developing a comprehensive system for mandating listed company disclosure, for proactively monitoring reports and for taking enforcement action against violators can be best achieved if the necessary authority to regulate and disclose is consolidated in a single entity. The Securities Services Bill as originally proposed in 2004 would have consolidated company financial disclosure reporting in the FSB. Given the inability of the DTI to act more than three years after passage of the amendments, it is unlikely that DTI will ever consider this a priority responsibility. Accordingly, assignment of this responsibility to the FSB, as proposed in 2004, appears to be the better approach.

The listing requirements adopted by the JSE for Alt ${ }^{x}$ securities appears to be a sound balance of lower company size and financial worth standards combined with greater prudential requirements.

Principle Holders of securities in a company should be treated in a fair and equitable manner.

15.

Description $\quad$ JSE rules contain a broad requirement that companies must treat all holders of the same class of security fairly and equally. Public companies that issue new stock must provide existing shareholders with a preemptive rights offering, unless a shareholders vote is obtained, with 75 percent of voting shareholders approving.

In South Africa, the King Commission has issued three reports on broad topics of corporate governance and policy. The JSE listing standards require companies to either comply with the recommendations contained in "King I, II and III" or explain in the annual report how they have not complied and why. Under the Companies Act, directors have a clear fiduciary obligation to act in the best interests of company shareholders as a whole.

In 2007, the amendments to the Companies Act contained a series of changes in corporate governance designed to improve shareholder protections. All companies are now required to separate the CEO and Board Chairman functions. Boards must have an audit committee of at least 2 members who are non-executive and required to "act independently". Auditors are required to rotate engagement partners on a 5 year cycle and may not contract to provide an audit client with non-audit services.

The Takeover Regulation Panel has broad responsibility for compliance with the takeover provisions of the Companies Act. Tender offers for 100 percent of company shares may be required from any holder of 35 percent of a company's shares. The tender must be priced at the highest price paid by the offeror and must be open for 21 days. DTI also has responsibility under the Companies Act for the conduct of annual shareholder meetings and voting. Regulation of material published by a company in conjunction with a general meeting of shareholders, including proxy solicitations and the timing requirements are contained generally in $\$ 190$ of the Companies Act. The JSE has augmented these requirements in its listing requirements. While the companies Act permits shareholders to provide proxies to anyone, there are no procedures governing third party proxy solicitations or contested voting. Since 1999, intermediaries holding legal title to shares must notify companies of the beneficial owners quarterly or as specifically requested by the company. The 2009 Companies Act amendments shortened this to one month. However, Brokers and other intermediaries have no obligation to distribute information on behalf of third parties in a proxy contest.

The 2000 assessment noted a deficiency in the public disclosure of holdings and transactions by corporate insiders and large shareholders. These problems have been partially eliminated. As described in principle 14, listed companies now must disclose 


\begin{tabular}{|c|c|}
\hline & $\begin{array}{l}\text { director holdings in the annual report and companies must publicly disclose any } \\
\text { changes within } 48 \text { hours of any purchase or sale. This requirement does not apply to } \\
\text { company officers who were not directors. Also, large independent shareholders in a } \\
\text { company with holding of more than } 5 \text { percent, must notify the company of their } \\
\text { holdings and of any changes in their holdings and the company is now required to } \\
\text { make this information public. } \\
\text { JSE rules on voluntary exchange delisting require a vote from a majority of all } \\
\text { shareholders, excluding the controlling shareholder and a fair offer must be made to } \\
\text { shareholders as confirmed by an independent expert. } \\
\text { The Companies Act provides for private litigation by shareholders; however they must } \\
\text { be able to establish money damages. }\end{array}$ \\
\hline Assessment & Broadly Implemented \\
\hline Comments & $\begin{array}{l}\text { The } 2008 \text { assessment update noted that the Companies Act and the JSE listing } \\
\text { requirements did not provide a process for third parties to solicit voting proxies from } \\
\text { shareholders to contest Director elections or influence other company decisions } \\
\text { requiring a shareholder vote. The amended Companies Acts now provides for } \\
\text { shareholders to provide proxies to third parties but does not specify procedures for } \\
\text { solicitation. } \\
\text { Section } 122 \text { of the amended Companies Act requires a company that has received } \\
\text { notification from a large shareholder of a change in ownership to make this } \\
\text { information public. The JSE has indicated that it intends to amend its Listings } \\
\text { Requirements to and require listed companies to make the information public via } \\
\text { SENS within } 24-48 \text { hours. } \\
\text { The pre-approval and notification requirements for company directors described in } \\
\text { principle } 14 \text { do not apply to company officers who are not also directors. }\end{array}$ \\
\hline $\begin{array}{l}\text { Principle } \\
16 .\end{array}$ & $\begin{array}{l}\text { Accounting and auditing standards should be of a high and internationally acceptable } \\
\text { quality. }\end{array}$ \\
\hline Description & $\begin{array}{l}\text { South Africa was one of the first countries to permit the use of IFRS, in 1999, and in } \\
2004 \text { IFRS was adopted as South African GAAP. The World Economic Forum has } \\
\text { recently given a high ranking to the South African accounting profession. } \\
\text { The } 2002 \text { ROSC on Accounting and Auditing Standards made a series of } \\
\text { recommendations for action. These included: a) creation of an accounting standards } \\
\text { body with full legal recognition and authority as well as an independent regulatory } \\
\text { body for auditors; b) adoption of internationally recognized standards on accounting } \\
\text { and auditing; c) strengthening the compliance and enforcement mechanisms for } \\
\text { accountants and auditors; d) providing the FSB with the legal authority to regulate } \\
\text { financial reporting, as well as monitoring and enforcing compliance. In } 2007 \text { the } \\
\text { Corporate Laws Amendment Act was passed. This law amended the Companies Act } \\
\text { of } 1973 \text { to address several recommendations of the } 2002 \text { Accounting and Auditing } \\
\text { ROSC. It required widely held companies to create an Audit subcommittee of its } \\
\text { Board, composed of two non-executive Board members. It imposed a five-year } \\
\text { rotation requirement on Audit engagement partners and created a ban on audit firms } \\
\text { providing non-audit services to audit clients. It created a Financial Reporting } \\
\text { Standards Council (FRSC), appointed by the Minister of DTI, to become the statutorily } \\
\text { authorized national accounting standards setter. This Committee was never formally } \\
\text { constituted and in } 2009 \text { the Companies Act was amended to replace it with a Financial } \\
\text { Reporting Standards Commission. As of May 2010, this body had not been formally } \\
\text { empanelled. The Accounting Policy Board (APB), the private sector accounting } \\
\text { standard setter continues to function in the interim. }\end{array}$ \\
\hline
\end{tabular}


While the APB does not have statutory recognition as the national accounting standards body, it has de facto recognition. Consistent with the policies of the IAS, the APB has been reluctant to issue interpretive positions or informal guidance on the application of IFRS, unless the IAS has provided guidance.

The Independent Regulatory Board for Auditors (IRBA) was created in 2005 by the Auditing Professions Act and is funded jointly by the government and the accounting industry. It is headed by a 10 member Board of Governors; appointed by the Minister of Finance. No more than 4 members may be audit professionals. The predecessor to the IRBA adopted international standards on auditing (ISA) in 2005. IRBA licenses and qualifies auditors. It has an on-site inspection program that reviews firm-wide operations and examines a sample audit engagement. IRBA has a disciplinary process. It also has requirements for member firms to formally notify it of "reportable irregularities" identified in the financial statements of a client.

In September 2008 the JSE, in conjunction with IRBA, established a qualification program for auditors of listed companies and subsidiaries of listed companies. To be qualified a firm must have demonstrated experience auditing listed companies and have undergone a firm-wide independent quality control review and should not be subject to a second re-review. The firm must have a minimum of three partners who have been qualified as a listed company auditor by IRBA. At least one must have demonstrated knowledge of JSE requirements and one must be a specialist in IFRS. Also, audit partners must attend mandatory training on JSE Listings requirements. As of 2010, there are 29 firms, 379 partners and 26 IFRS specialists accredited with the JSE.

Also in 2008, the JSE adopted a requirement that listed companies must appoint a financial Director from the company to the Board. The person appointed must be approved by the Audit Committee of the Board and reassessed by the Audit committee annually.

The JSE has an informal process for advising listed companies on the appropriate accounting treatment and disclosure requirements through its GAAP monitoring panel (GMP). However, this process is restricted to matters referred by JSE issuer services. The GMP will not provide advance clearance or advice to companies or auditors. The JSE may ask the GMP for guidance on accounting matters. If there is a dispute between the JSE and a listed company then it will ask the GMP for an authoritative view on the matter. The GMP reports are submitted to the JSE in writing providing their reasoning.

$\S 45$ of the Auditing Profession Act requires an auditor to notify the IRBA and the audit committee of the company of "reportable irregularities". The auditor must then meet with the audit committee to discuss the irregularity and report to the IRBA that the irregularity has been addressed or is still unresolved. The IRBA must notify the appropriate government regulators of the incident. The IRBA has a policy of not making these reports public.

Comments Broadly Implemented

The 2008 assessment update highlighted the importance of the DTI moving forward on the creation of the Financial Reporting Standards Council to supercede the APB as the national standard setter. This has not happened and the APB is continuing to function as an unofficial standard setting group. The broadly implemented assessment is due to the delay in establishing this legally authorized accounting standard setter.

While the notice to IRBA of reportable irregularities is a sound process, consideration should be given to a requirement that the company affected must publicly disclose the matter at an appropriate time. One possibility would be to require a company, after the 
meeting between the audit committee of the board and the auditor, to disclose what action was taken or, if no action was taken, the reasons for not taking action. This is merely one possibility however and the appropriate regulatory body may want to solicit broad public comment on the question. The FSB believes that reportable irregularities must be disclosed if there is any qualification or modification to the audit report. It is not clear if this would apply to all possible reportable irregularities.

As indicated previously, the IRBA should reexamine the public policy reasons for not publicizing final disciplinary actions taken.

\section{Principles for Collective Investment Schemes}

\section{Principle} 17. Description
The regulatory system should set standards for the eligibility and the regulation of those who wish to market or operate a collective investment scheme.

The FSB is the registrar of managers under CISCA and of asset managers under FAIS. The application and approval process is based upon a written form. FSB approval is required before a CIS may begin operations. The FSB approval process requires submission of an application containing detailed information on the CIS, and its management personnel. A key aspect of the FSB review is a fit and proper test for key management. The FSB has published rules concerning the application of the fit and proper test. As part of the review process the FSB looks at the chairperson, directors, chief executive, trustee, investment manager, auditor and compliance officer of the applicant company. FSB approval also requires a "public interest" finding.

A manager under CISCA must be created as a separate legal entity. A subsidiary of a holding company must have minimum $R 600,000$ basic capital and each fund must have R 1 million initial seed capital (reduces by 10 percent for each $R 1$ million new investments received and position risks capital for money market funds of 10 percent, income funds of 15 percent and 25 percent for all other funds).

While there is no education or testing requirement for a CIS manager, the asset manager of a CIS portfolio must be separately licensed under FAIS (category II FSP). The requirements for FAIS registration are discussed under principle 21.

Foreign CIS must apply for approval under CISCA to market their products locally. FSB approval is based upon a satisfactory home country regulatory environment and risks involved in the product offered.

Following registration all CIS managers must receive FSB approval to change structure, directors, shareholding, as well as all outsourcing arrangements such as asset manager or service provider. CISCA contains a broad prohibition on conflicts of interest between CIS manager and investors and a disclosure obligation on relationships. A CIS manager must apply "know your customer" principles when taking money for investment from new clients.

All CIS must submit quarterly reports to the FSB, within 30 days of quarter end. The report must contain a full list of all portfolio assets including the market value of each asset and the value of each asset as a percentage of the total value of assets in the portfolio and as a percentage of the total amount of assets of that class from one issuer. The report must also indicate which assets are not exchange securities. If any asset is not listed on an exchange, the manager must indicate how it priced the asset. Annual reports containing sdited financial statements must also be submitted to the FSB.

The FSB has an extensive CIS inspection and review program. FSB staff review all filed reports. Each CIS group is subject to an onsite inspection by the FSB. In addition, fund managers are subject to review by FSB staff for compliance with FAIS. 
"White label" funds are a distinct, unofficial category of CIS portfolio. A white label fund contracts with a licensed CIS manager to act as host for the establishment and administration of a CIS that is managed by a third party and branded in the name of the third party. The CIS manager at all times retain the ultimate responsibility for all the duties performed in respect of third party portfolios. The asset manager must obtain a license under FAIS, however.

\begin{tabular}{l|l} 
Assessment & Fully Implemented \\
\hline Comments & $\begin{array}{l}\text { Since the } 2008 \text { assessment update, the FSB has taken several actions that address } \\
\text { concerns raised in that assessment and is progressing on other initiatives. It has } \\
\text { adopted a capital adequacy requirement for FAIS registrants and it has expanded its } \\
\text { requirements for CIS asset managers, registered under FAIS. }\end{array}$
\end{tabular}

The FSB has indicated that it developing qualification standards for CIS managers that will parallel and conform to the standards established under FAIS. Achieving regulatory consistency in qualifications is encouraged.

Principle $\quad$ The regulatory system should provide for rules governing the legal form and structure 18. of collective investment schemes and the segregation and protection of client assets.

Description $\quad$ Collective investment schemes are usually created as trusts, administered by a manager, with the assets controlled by an independent trustee. CIS funds may also be created as a corporate structure and listed and traded on the JSE.

The trust agreement establishes the responsibilities of the manager and trustee and custodian (if applicable) and such custodian must also be non-affiliated. Under CISCA, the trustee may not be affiliated with the manager. The 4 largest banks in the country act as trustees. Any changes to the trust agreement or the management of the CIS must be approved by the FSB. If a change affects the rights of investors, the investors must also approve such change. Investors must be notified three months in advance of any increase in fees.

The trustee has liability for willful or negligent loss of assets and must report annually to the FSB on CIS compliance with CISCA and compliance with the trust agreement. If a CIS decides to windup a fund, it must submit an application to the FSB or a court in South Africa may order it. CIS assets must be independently audited annually. FSB rules require detailed recordkeeping of all transactions by a CIS.

While LISPs are technically regulated under FAIS, not CISCA, they function in ways that are similar to a CIS. A LISP accepts the investments of clients and reinvests them as a consolidated amount in other vehicles (typically CIS funds) in the name of the LISP. A LISP can only act upon instructions of clients or their advisors and are not responsible for the underlying assets under control of the CIS manager. Because a LISP is not considered a CIS it does not have the legal duty to use unaffiliated trustees/custodians to protect investor assets. Instead the FSB requires that LISP assets must be deposited with an independent nominee, subject to FSB approval. The nominee must be under the control of a board of trustees, a majority of whom must be independent The FSB also requires these nominees to report annually to the FSB. This is discussed under market intermediary principles below.

There is a developing hedge fund industry in South Africa, with assets under management estimated at approximately $R 30$ billion with approximately $R 14$ billion additional under management by funds of hedge funds. Under South African law there is no concept of a "sophisticated" or "qualified high net worth" investor and there is no basis for creating hedge funds that could be exempted from the general requirements of CISCA. As such these pools of assets are not regulated as collective investment schemes (although the asset managers must be licensed under FAIS). Because 


\begin{tabular}{|c|c|}
\hline & $\begin{array}{l}\text { South African law does not prescribe a particular structure that readily fits a hedge } \\
\text { fund, hedge funds may be structured in different ways, such as a pooled investment in } \\
\text { limited partnerships or as a company that issues interests that are termed debentures } \\
\text { or promissory notes. An investment in a hedge fund may also be made via an } \\
\text { insurance company product that invests in the hedge fund. These policies (minimum } \\
\text { five years) provide a return pegged to the total return of the hedge fund pool of assets } \\
\text { identified in the policy. }\end{array}$ \\
\hline Assessment & Broadly Implemented \\
\hline Comments & $\begin{array}{l}\text { In } 2008 \text {, the FSB indicated that it would regulate hedge funds through its authority to } \\
\text { regulate asset managers under FAIS but that hedge fund products would not be } \\
\text { regulated, as it would not be possible under CISCA. The FSB has indicated that it is } \\
\text { reconsidering this stance and is studying how to create a regulatory regime for hedge } \\
\text { fund products, as a complement to its regulatory standards for the hedge fund asset } \\
\text { manager. If adopted the regulatory regime for hedge fund products would focus on } \\
\text { systemic risk issues and the structure of the hedge fund. Additional legal authority } \\
\text { may be required. Because this issue requires coordination with other bodies, such as } \\
\text { the Ministry of Finance and SARB, there is not timetable as yet. When the legal } \\
\text { uncertainty over the structure and regulation of hedge fund products is resolved, this } \\
\text { assessment should be fully implemented. } \\
\text { The FSB It is also reviewing its position on "white label" funds to ensure that its } \\
\text { existing approach of regulating the registered management company under CISCA } \\
\text { and the portfolio manager under FAIS is sufficient. }\end{array}$ \\
\hline $\begin{array}{l}\text { Principle } \\
19 .\end{array}$ & $\begin{array}{l}\text { Regulation should require disclosure, as set forth under the principles for issuers, } \\
\text { which is necessary to evaluate the suitability of a collective investment scheme for a } \\
\text { particular investor and the value of the investor's interest in the scheme. }\end{array}$ \\
\hline Description & $\begin{array}{l}\text { A CIS is not required to prepare a full prospectus or offering statement. Instead of a } \\
\text { prospectus or offering statement, a CIS uses its Deed, or trust agreement, that is the } \\
\text { formal terms of the trust, which must be approved by the FSB. Companies must } \\
\text { provide it to investors upon request, but may charge a fee. } \\
\text { Section } 3 \text { of CISCA requires CIS to provide investors with information about } \\
\text { investment objectives, the calculation of the net asset value, charges, risk factors and } \\
\text { distribution of income accruals. It also contains a broad requirement to disclose } \\
\text { information that is necessary to enable the investor to make an informed decision. The } \\
\text { industry standards for meeting these requirements are contained in unofficial guides } \\
\text { prepared by the ACI (now ASISA). } \\
\text { Typically a CIS will market through a fact sheet, compliant with ASISA standards. The } \\
\text { FSB requires non-ASISA members to abide by ASISA standards, as a condition of } \\
\text { FSB approval. The ASISA code requires the marketing document to disclose the fees } \\
\text { to be charged, as well as a total expense ratio (including management fees but } \\
\text { excluding certain expenses discussed in the comments), investment strategy and risk } \\
\text { factors, information on the asset manager, trustee information on asset valuations } \\
\text { methods and procedures for investment and redemption. Performance information } \\
\text { may be disclosed in a minimum of a one-year performance period or six months if the } \\
\text { portfolio is less than one year old. The ACI recommends but does not require } \\
\text { inclusion of an index for comparison of performance. } \\
\text { ASISA has adopted the Code of Advertising created by ACI (now ASISA), } 5 \text { other } \\
\text { codes of conduct, } 18 \text { guidelines and } 15 \text { standards. There is a three tiered } \\
\text { classification system for funds - geographic (domestic, foreign or worldwide), asset } \\
\text { allocation (equity, fixed-income, real estate, or asset allocation of all three); and focus } \\
\text { (growth, financial or general, value, large-cap, small cap, specialty or sector). }\end{array}$ \\
\hline
\end{tabular}


There are also several prudential limitations on investment. These include the following: a maximum of 10 percent of fund assets may be invested in unlisted securities for no more than 12 months; a maximum of 25 percent of assets may be invested in foreign securities; no more than $5 / 10$ percent of assets may be invested in a single security and a fund may not own more than $5 / 10$ percent of a company's single issue of shares. No more than 15 percent of fund assets may be invested in securities of affiliates of the Manager and no more than 24 percent in a different group of affiliated companies.

CISCA requires a CIS to prepare annual audited financial statements and submit them to the FSB and ASISA, within 90 days of fiscal year end. Investors may obtain copies on request. The ASISA code on investor communication requires managers to provide investors with "such information relating to the state of affairs and results of the operation of the collective investment scheme as may be prescribed by CISCA and the conditions thereto." The ASISA code requires this to include: 1) an abridged income statement and balance sheet of portfolio; 2) a report by the chairman or managing director disclosing material facts or circumstances which had an effect on the portfolio and any deviations from investment policy; 3 ) amounts and dates of distributions; 4) performance figures for the current and previous year; 5) all charges to investors and changes in the charges or methods of calculation; 6) any auditor qualifications to financial statement; 7) a trustee/custodian report on administration of the fund; and 8) a statement on the availability of the Shar'iah Supervisory board report, if applicable.

An updated quarterly report (which contains the full portfolio of assets and prices and percentage limits) must be filed with the ASISA (10 days after quarter end) and the FSB (30 days after quarter end). Managers may voluntarily send an edited version of these quarterly statements to investors and must provide access to the report at its registered office and authorized branch offices on request.

Assessment Partly Implemented

Comments
A core responsibility of a capital market regulator is investor protection. This requires a regulator to establish a regulatory framework that ensures that investors have necessary information to determine whether to make an investment decision. This principle is expressly included in the CISCA. However, while CISCA contains this broad statement of regulatory principles, requiring CIS to provide investors with necessary information, the practical instructions on what is satisfactory compliance is contained in nongovernmental industry codes of conduct. If ACI/ASISA had developed these codes and been registered as an industry self-regulatory organization, this would have been a compliant regulatory method. However that is not the case. A system in which a government agency delegates to an industry trade group, not registered as an SRO, broad responsibility to set mandatory policy on business conduct is unusual, and when this unofficial body also is largely responsible for monitoring compliance, the problem becomes even greater.

The disclosure policies that have been established are generally sound but anomalies exist. For example, managers are free to use affiliated brokers to execute all trading, with no requirement for negotiation of trading costs. This creates a potential conflict of interest. While a manager must disclose an annual ratio of expenses, it does not include brokerage/trading expenses. There is also no requirement to disclose a list of all, or a representative selection of the largest, fund holdings. Several years ago, an incident occurred which demonstrates the problem. A money market fund, which invested in inappropriate high risk notes may have been mitigated or discovered sooner if investors could see the fund's portfolio and learn how the fund was earning significantly above market returns. Funds are also not required to disclose fund turnover rates. 


\begin{tabular}{|c|c|}
\hline & $\begin{array}{l}\text { The greatest concern however is the legal status of these requirements. They were } \\
\text { developed by an industry trade group that was never licensed as a self-regulatory } \\
\text { organization and no longer exists. They have been adopted by a new trade group that } \\
\text { is not an SRO and has no intention of becoming one. The FSB has indicated that no } \\
\text { formal delegation of authority to ASISA exists. While the codes and standards are in } \\
\text { fact the industry reference point, this is purely voluntary. Accordingly, the FSB should } \\
\text { carefully examine the current industry standards and, if the FSB believes that they are } \\
\text { what is appropriate, then the FSB should formally adopt them through an FSB } \\
\text { directive. Because there is no clearly binding statement of disclosure requirements for } \\
\text { CIS, this principle is assessed partly implemented. Formal FSB action would eliminate } \\
\text { this problem. }\end{array}$ \\
\hline $\begin{array}{l}\text { Principle } \\
20 .\end{array}$ & $\begin{array}{l}\text { Regulation should ensure that there is a proper and disclosed basis for asset } \\
\text { valuation and the pricing and the redemption of units in a collective investment } \\
\text { scheme. }\end{array}$ \\
\hline Description & $\begin{array}{l}\text { The CIS manager is required to calculate NAV daily and the trustee is responsible for } \\
\text { confirming the accuracy of the calculation, although there does not appear to be a } \\
\text { requirement for daily confirmation. According to the FSB, in practice three out of the } \\
\text { four trustees do it on a daily basis. The calculation must be based upon current } \\
\text { market pricing when available or fair value pricing, obtained from the JSE or a pricing } \\
\text { authority or non-affiliated broker. The ASISA requires daily publication by retail funds } \\
\text { of NAV (and max. initial percent fee) in at least one national newspaper. } \\
\text { CIS managers must provide monthly reports to the FSB on capital adequacy and } \\
\text { quarterly review of regulatory compliance with investment limits. } \\
\text { The formula for calculation of redemption pricing must be disclosed in the CIS Deed. } \\
\text { Typically it is within } 24 \text { hours after receipt of request. Payment normally occurs within } \\
\text { two business days. A fund may suspend redemption for up to } 20 \text { days, with } \\
\text { permission of its trustee, and it must notify the FSB and provide an explanation. }\end{array}$ \\
\hline Assessment & Fully Implemented \\
\hline Comments & $\begin{array}{l}\text { Accurate pricing of illiquid assets is a common problem in many countries. For this } \\
\text { reason regulatory authorities must closely monitor fair value pricing methodologies, } \\
\text { both for accuracy and consistency across competitors. Variations in fair value pricing } \\
\text { methodologies could distort the comparative performance of funds and affect investor } \\
\text { decisions. } \\
\text { Linked investment service providers (LISPs) are discussed separately in the next } \\
\text { principle. While they are regulated under FAIS, the product they provide may closely } \\
\text { resemble a CIS fund of funds where the LISP invests clients' money in CIS. An } \\
\text { investor in a LISP receives account statements that identify the amounts held in each } \\
\text { discrete CIS and the CIS NAV. Because these investments are held by a CIS in the } \\
\text { name of the LISP, only the LISP has the capacity to determine the actual investments } \\
\text { for each investor. While this is not a question of net asset value calculations, it is an } \\
\text { analogous issue of ensuring that the administrative systems used by LISPS are } \\
\text { sufficiently robust to accurately account for, track to the correct customer and assign } \\
\text { correct prices to each asset of each investor. Because of the number of small } \\
\text { investors who rely upon LISPs to manage their investments, careful ongoing oversight } \\
\text { of LISP procedures for recording investor holdings and values is needed to reduce the } \\
\text { possibility of fraud by a LISP manager. }\end{array}$ \\
\hline \multicolumn{2}{|r|}{ Principles for Market Intermediaries } \\
\hline $\begin{array}{l}\text { Principle } \\
21 .\end{array}$ & Regulation should provide for minimum entry standards for market intermediaries. \\
\hline Description & $\begin{array}{l}\text { The FSB and JSE share responsibility for initial licensing and ongoing oversight of } \\
\text { market intermediaries in South Africa. } \$ 7 \text { of the Financial Advisory and Intermediary } \\
\text { Services Act of } 2002 \text { (FAIS) requires persons who furnish advice or render } \\
\text { intermediary services (financial service providers or FSP) to be licensed by the FSB. } \\
\text { The JSE licenses and oversees its licensed members (authorized users). These }\end{array}$ \\
\hline
\end{tabular}


entities are not required to be licensed under FAIS, unless they provide additional financial services not regulated by the JSE.

There are four categories of financial service provider registered under FAIS. Category 1 is the largest (over 14,000 in 2008). This category includes FSPs who render advice without exercising discretionary authority. Category II FSP who exercise discretionary authority over client funds (446 in 2008). This category includes portfolio managers of CIS. Hedge fund managers are in Category IIA (127 in 2008). Category III FSP (21) who provide collective investment opportunities for small investors, commonly called linked investment services providers (LISP). In 2009 a new category IV was created for FSP who provide business administration services. As of 2008 , the total assets under management for all FSP, except category I, exceeded R 3.5 billion.

The FSB applies a fit and proper test to the applicant and to the officers, directors, board members, trustees and supervisors at the applicant who are responsible for managing and overseeing activities. Other employees must also meet the fit and proper requirements and it is the responsibility of the applicant firm to make that decision ( $\$ 14$ of FAIS imposes a duty on the licensee to prohibit its representatives from providing financial services if the licensee determines that the person does not satisfy the fit and proper test). A licensee must notify the FSB within 15 days of a decision to debar an employee.

The fit and proper requirement has four parts - honesty and integrity, competency, operational ability, and financial soundness. The third part, competency, includes academic qualifications, experience in the relevant area of financial services, and an ongoing continuing education requirement. To achieve full competency, an applicant must have 120 credits of study. Beginning in 2011, the FSB will require applicants to pass specialized exams administered by designated private testing services on specific financial products. Designated supervisors must have supervisory experience, and designated compliance officers must have a separate accreditation, including demonstrated knowledge of legal requirements.

Applicants in categories IIA (hedge funds) and III (LISP) will typically have FSB on-site visits as part of the application review process. As described in principle 10, the FSB conducts on-site inspections of selected intermediaries, based upon a risk-based assessment system that is heavily weighted to firms with the largest amount of investor funds. The JSE conducts on-site inspections of all of its members. Under $\S 15(1)$ of FAIS, the FSB has enacted a broad general code of conduct. Reporting by licensees and periodic reporting requirements are discussed in principle 8 , inspection.

The FSB retains the authority to suspend or revoke a license granted, or to modify or impose conditions on its approval, if it determines that the licensee is not in compliance with the law or FSB rules or if there has been a change in the operation of the licensee or a key individual. An opportunity for a prior hearing is required. The action of the registrar may be appealed to the Appeal Board.

As noted, JSE members are exempt from registration under FAIS if all of their advisory and intermediary activities fall within the rules of the JSE and are therefore regulated by the JSE. The JSE has several categories of members, including fullservice brokers, who trade for customers and for the firm and who have control over customer accounts, brokers who introduce for customers but do not process or retain control over customer accounts, and member firms that trade only on a proprietary basis.

The regulatory principles that apply to FAIS registrants and JSE member firms are similar. Registrants in both regimes must adhere to broad principles of fair dealing, 


\begin{tabular}{|c|c|}
\hline & $\begin{array}{l}\text { owe fiduciary duties to customers and must apply "know your customer" principles } \\
\text { when making investment recommendations. Internal control, risk management and } \\
\text { internal compliance responsibilities are also similar. } \\
\text { Category III includes LISPs, a special type of FSP. A LISP provides investors with the } \\
\text { ability to invest assets in a more than one family of CIS portfolios through a common } \\
\text { pooled account managed by the LISP. In addition to this investment flexibility, LISPs } \\
\text { use the size of the common asset pool to negotiate lower sales charges with CIS. } \\
\text { They claim that the lower sales fees offset the asset management fee they charge. } \\
\text { While most LISPs do not provide investment advice and require investors to work } \\
\text { through a financial advisor, a small number offer this service for an additional fee. } \\
\text { The LISP industry has grown to become a substantial segment of the financial } \\
\text { services industry. It is estimated that } 1 / 3 \text { of the investments in CIS come from LISPs. }\end{array}$ \\
\hline Assessment & Fully Implemented \\
\hline Comments & $\begin{array}{l}\text { The } 2008 \text { assessment update recommended that the FSB consider creating a special } \\
\text { qualification requirement for individuals under FAIS based on the types of products or } \\
\text { services offered. This has been accomplished, with a special education requirement } \\
\text { and a continuing education requirement tied to specific types of financial products. } \\
\text { Compliance will be phased in over a three year period. } \\
\text { Category II includes all persons who have discretionary authority over client funds. } \\
\text { This includes private managers of individual accounts and portfolio managers under } \\
\text { CIS. Given the significant differences between these two types of professionals, it may } \\
\text { be appropriate to separate CIS portfolio managers into a separate subcategory. } \\
\text { Now that the FSB has adopted standards on education and experience, it should } \\
\text { consider, as part of its application review process, affirmatively validating the } \\
\text { information provided in the application. FSB staff has indicated that this is being done } \\
\text { for CIS applications. Similarly, consideration should be given to adopting standards on } \\
\text { what level of effort and due diligence FAIS managers must make when conducting the } \\
\text { same qualification review of employees who are not subject to the FSB review } \\
\text { process. } \\
\text { FAIS managers are required to notify the FSB within } 15 \text { days of any action to debar an } \\
\text { employee who fails to meet or ceases to meet the fit and proper requirements. In } \\
\text { other jurisdictions with a comparable requirement, a problem occasionally occurs } \\
\text { whereby a manager will allow an employee rather than be debarred. In this way the } \\
\text { employee avoids notification of the FSB, making it possible for the employee to obtain } \\
\text { a job with another firm. There is no indication that this is currently a problem in South } \\
\text { Africa. However, because it occurs in other jurisdictions with comparable policy, the } \\
\text { FSB should consider whether regulatory guidance to FAIS managers is needed. }\end{array}$ \\
\hline $\begin{array}{l}\text { Principle } \\
22 .\end{array}$ & $\begin{array}{l}\text { There should be initial and ongoing capital and other prudential requirements for } \\
\text { market intermediaries that reflect the risks that the intermediaries undertake. }\end{array}$ \\
\hline Description & $\begin{array}{l}\text { Stockbrokers registered with the JSE must adhere to the JSE capital adequacy } \\
\text { standard. While there is no explicit requirement in the JSE rules for member firms to } \\
\text { calculate capital adequacy on a daily basis, JSE requires that member firms must be } \\
\text { assured that they have adequate capital every day and report monthly to the JSE, } 10 \\
\text { days after the month end. The JSE relies heavily on its on-line monitoring of equities } \\
\text { member firms positions. Firms must enter all cash trading and derivatives trading by } \\
\text { 7:00 pm cob on each trading day. JSE members' listed derivative positions feed } \\
\text { automatically into the JSE's capital adequacy system from the derivatives clearing } \\
\text { system. The members separately report their OTC derivative positions to the JSE via } \\
\text { an electronic reporting system. The JSE's capital adequacy system calculates the } \\
\text { member's risk by netting the cash equity positions against the cash equivalent of their } \\
\text { listed and OTC derivative positions to determine the member's market exposure for }\end{array}$ \\
\hline
\end{tabular}


each equity instrument. JSE internal systems prepare cob each day, an internal report on equities member firm's open risk positions and available liquid funds. If the internal report reflects that a firm may not meet the minimum requirements, JSE staff will contact the firm and obtain additional information in order to establish whether there is a real shortfall. If a shortfall is confirmed, the firm is required to remedy the situation by either closing out risk positions or injecting additional capital. If the JSE is of the view that a capital shortfall poses a threat to the market or a firm's clients, an Urgent Issues Committee can suspend the firm from trading. If this Committee does not take action, then the firm may continue to do business. The JSE estimates that the majority of daily trading volume on the JSE is concentrated in the ten largest member firms.

The 2008 assessment update highlighted the absence of specific capital adequacy standards for FAIS registrants. In 2009, the FSB adopted a capital adequacy standard for FAIS registrants, with different requirements based upon each FAIS category. Existing licensees have been given a two-year period to achieve compliance. New licensees must comply when licensed. The FSB directive requires licensees to report capital on a quarterly basis. There is no requirement to calculate capital compliance more frequently. Licensees are also not required to alert the FSB when capital levels approach minimum capital required (an early warning system).

In September 2010, the FSB will begin requiring new licensees to obtain fidelity bonds (R 5 million). Licensees must also keep client funds in a segregated trustee account, with a non-affiliated trustee, typically a bank. All customer funds must be transferred into this account within 14 days of receipt. The account must be independently audited annually.

JSE rules require member firms to hold client cash positions in a custodian account controlled by a JSE subsidiary. While equity positions of the firm and its customers are contained in an omnibus account, JSE internal systems maintain segregated records. JSE rules prohibit firm borrowing of customer securities.

Assessment

Comments

\section{Broadly Implemented}

The adoption of a capital adequacy requirement under FAIS has filled an important gap. The standards adopted appear to be carefully conceived and appropriate. However the effectiveness of a capital adequacy standard depends upon the system for use and compliance. To be fully implemented the FSB should adopt an early warning system requirement that firms calculate capital on a more frequent cycle ( e.g., daily, weekly or monthly) and require firms to notify the FSB whenever capital approaches the legal minimum.

The JSE capital adequacy requirements are consistent with international norms and the JSE monitoring systems contain a robust amount of information concerning member firms that is updated daily. This reduces the risks that would ordinarily arise when firms are required to submit capital adequacy reports monthly. Nonetheless the system is not ideal. While OTC derivatives and listed derivatives are separately reported to the JSE, the OTC derivatives are netted with listed derivatives for capital adequacy calculation, notwithstanding that the instruments may contain different collateral and settlement requirements, and create counterparty risks arising from excessive concentration with individual or affiliated clients. For these reasons, it may be possible to obscure the firm's true risk exposure. The issue of how OTC derivative positions, with non-standard collateral and settlement terms are dealt with for capital adequacy purposes should be examined as part of the OTC Study previously discussed. ensure proper management of risk, and under which management of the intermediary 
accepts primary responsibility for these matters.

\begin{tabular}{|l|l|}
\hline Description & $\begin{array}{l}\text { FAIS requires registered firms to have compliance officers, except in the case of sole } \\
\text { proprietors. If the applicant is not a single person, then it must have a designated } \\
\text { compliance officer responsible for internal controls, risk management and supervisory } \\
\text { systems. The FSB permits firms to fulfill this obligation by retaining third party } \\
\text { companies to serve as compliance officers. Currently there are } 34 \text { firms that the FSB } \\
\text { has recognized to perform compliance services. The FSB reports that it is developing } \\
\text { standards for these external compliance firms. The JSE reports that it requires all } \\
\text { member firms to have a compliance officer. It does not permit firms to rely upon third } \\
\text { party external compliance officers. }\end{array}$
\end{tabular}

The adequacy of internal controls must be reviewed as part of a licensee's annual external audit. Under the FSB code of conduct for FAIS registrants, there is a duty to disclose relationships with product suppliers, disclose all direct and indirect remuneration and conflicts of interest; and disclose all fees. The code relies heavily upon a general principle on disclosure - adequate and appropriate in relation to the level of knowledge of the consumer; timely and in plain language.

Under FAIS, there is also a general fiduciary obligation to investors under FAIS. The JSE imposes an affirmative know your customer requirement on member firms and also for cash equities there is a best execution rule. Firms must maintain detailed customer account records and have a written plan for reviewing and responding to customer complaints. The FSB examines the customer complaint records of firms when it conducts on-site inspections.

Assessment $\quad$ Broadly Implemented

Comments $\quad$ While CISCA prohibits the asset manager and custodian of a CIS from being affiliates, there is not a comparable prohibition for LISPs. Instead the FSB, through its licensing authority, requires that a majority of directors or trustees of a LISP custodian must be independent and the FSB requires the custodian to report directly to the FSB. Consideration should be given to augmenting these requirements by prohibiting a LISP from using an affiliated entity as a custodian, if this is possible.

The FSB is in the process of implementing, under FAIS, prohibitions on the giving and receiving of incentives that are deemed to create conflicts of interest. It is also increasing the disclosure requirements of those incentives that a provider may receive.

The use of a third party compliance company to satisfy regulatory requirements is an interesting approach to a common problem, how can a small firm afford the cost of full-time internal personnel who possess adequate training and competency. The problem for a regulator with this approach is to ensure that the third party company provides an appropriate level of service, to ensure that the third party has a sufficient number of qualified personnel to service the needs of its clients and to ensure that the regulator has the legal authority to conduct on-site examinations of the company to confirm that it is performing its responsibilities. The FSB does not at present have the clear authority to conduct on-site visits. It intends to seek this authority and to examine the two other issues identified.

Principle $\quad$ There should be a procedure for dealing with the failure of a market intermediary in $24 . \quad$ order to minimize damage and loss to investors and to contain systemic risk.

Description $\quad$ The FSB can order a licensee to suspend operations or to stop taking in new business. The FSB reports that its termination and suspension letters require the registrant to notify its clients of the action. The FSB also discloses this on its website.

The FSB also has legal authority to direct a manager to transfer assets to another portfolio manager. This action may be challenged by the licensee in civil court. 


\begin{tabular}{|c|c|}
\hline & $\begin{array}{l}\text { However a legal challenge will not stay the effectiveness of the transfer order. The } \\
\text { appropriate FSB registrar may also request a court to appoint a curator in the event of } \\
\text { a licensee failure. } \\
\text { The JSE internal systems provide detailed access to firm positions and open } \\
\text { exposures and provide an effective early warning system. It has the authority to order } \\
\text { an authorized user to suspend operations if it defaults on trades and can also suspend } \\
\text { operations if the firm is below minimum capital adequacy. The JSE also has the } \\
\text { authority to take over a defaulting member for the purpose of ensuring the settlement } \\
\text { of outstanding transactions and the return of client assets. } \\
\text { The JSE has a R } 750 \text { million omnibus fidelity bond to reimburse clients who were } \\
\text { defrauded by a member of the JSE. The maximum amount from the fund that may be } \\
\text { used for a loss by a single firm is R } 250 \text { million. In addition to this, the SSA also } \\
\text { requires the JSE to have a separate guaranty reserve fund, required under its bylaws } \\
\text { to be a minimum of R } 50 \text { million. As of } 2010 \text {, the fund held R } 200 \text { million. }\end{array}$ \\
\hline Assessment & Fully implemented \\
\hline Comments & $\begin{array}{l}\text { The FSB relies heavily upon quarterly reporting by FAIS registrants to monitor firm } \\
\text { risks. As noted previously, FAIS licensees that have investment discretion must report } \\
\text { on a quarterly basis, other FAIS licensees such as LISP file annual reports. Because } \\
\text { firms are not required to calculate capital on a daily or weekly basis, and because } \\
\text { there is no early warning reporting requirement (discussed in principle 22), it is } \\
\text { possible that the FSB may not become aware of a licensee's insolvency until after it } \\
\text { occurs. Even though the FSB possesses strong legal authority to take emergency } \\
\text { action, it may not be able to act until after the default has occurred, } \\
\text { The South African financial services industry is highly concentrated. Because brokers } \\
\text { and financial intermediaries are typically separately incorporated subsidiaries of larger } \\
\text { financial institutions, it is difficult for the FSB or the JSE to be fully aware of the } \\
\text { financial position of the consolidated entity. } \\
\text { While the FSB has an advantage as the regulator of financial intermediaries, } \\
\text { insurance companies, collective investment schemes and pension funds and reports } \\
\text { that it has strong working relations with the SARB, it is still difficult to be certain that } \\
\text { the distinct regulatory staff is aware of the overall picture. Consideration should be } \\
\text { given to developing a procedure for informal coordinating meetings of the staff } \\
\text { responsible for each component subsidiary of the largest consolidated entities. } \\
\text { Principle } 24 \text { requires regulators to have clear plans for dealing with the eventuality of a } \\
\text { firm's failure, including a combination of activities to restrain conduct, to ensure } \\
\text { assets are properly managed and to provide information to the market as necessary. } \\
\text { While the FSB and JSE, in combination have the capacity to take these actions, it } \\
\text { would be beneficial to formulate a clear written plan of action. }\end{array}$ \\
\hline \multicolumn{2}{|r|}{ Principles for the Secondary Market } \\
\hline $\begin{array}{l}\text { Principle } \\
25 .\end{array}$ & $\begin{array}{l}\text { The establishment of trading systems including securities exchanges should be } \\
\text { subject to regulatory authorization and oversight. }\end{array}$ \\
\hline Description & $\begin{array}{l}\text { The JSE is licensed under the Securities Services Act of } 2004 \text {. The Act contains a } \\
\text { comprehensive set of requirements that an exchange must meet to be registered. In } \\
\text { addition to demonstrating adequate financial, operational and personnel resources, it } \\
\text { must have the capacity to set and enforce trading rules, register and regulate its } \\
\text { members, set listing requirements for issuers of securities, and enforce compliance } \\
\text { with them, and provide clearance and settlement facilities. } \\
\text { The JSE utilizes the London Stock Exchange trading platform. This is a fully } \\
\text { automated direct interaction system that matches and buy and sell orders, without the }\end{array}$ \\
\hline
\end{tabular}




\begin{tabular}{|c|c|}
\hline & $\begin{array}{l}\text { use of a specialist or marketmaker. An open book system provides all participants with } \\
\text { full access to the best outstanding bid-asks. There is a full audit trail that is available } \\
\text { for analysis by the FSB. }\end{array}$ \\
\hline Assessment & Fully Implemented \\
\hline \multicolumn{2}{|l|}{ Comments } \\
\hline $\begin{array}{l}\text { Principle } \\
26 .\end{array}$ & $\begin{array}{l}\text { There should be ongoing regulatory supervision of exchanges and trading systems, } \\
\text { which should aim to ensure that the integrity of trading is maintained through fair and } \\
\text { equitable rules that strike an appropriate balance between the demands of different } \\
\text { market participants. }\end{array}$ \\
\hline Description & $\begin{array}{l}\text { Under the SSA, the JSE must have its license renewed annually. In addition to } \\
\text { information required in its initial application, it must submit a self-assessment form on } \\
\text { compliance with all requirements and SRO duties. As part of the license renewal } \\
\text { process the FSB conducts an annual on-site examination of the JSE. The annual } \\
\text { inspection focuses on critical JSE programs and issues raised in previous inspections. } \\
\text { As part of its oversight program, FSB staff attend all JSE Board and subcommittee } \\
\text { meetings. } \\
\text { The JSE must submit all rule changes to the FSB for formal approval. The FSB } \\
\text { reviews all new rules and rule changes, except those pertaining to listing } \\
\text { requirements, as well as all new types of products. It has a consultative function on } \\
\text { JSE listing requirements. The FSB may reject a rule or order the adoption of a } \\
\text { temporary rule. } \\
\text { The JSE has real time surveillance systems and a staff of } 3 \text { who monitor equities } \\
\text { trading, } 2 \text { who monitor derivatives trading and } 3 \text { for bond trading. Although the FSB } \\
\text { does not have direct on-line access to JSE surveillance systems, FSB staff meets } \\
\text { weekly with the JSE surveillance team to discuss trading anomalies and possible } \\
\text { market abuse practices that require further investigation by the FSB. During these } \\
\text { meetings, an FSB employee personally examines trading in the shares of the JSE } \\
\text { during the past week. } \\
\text { The JSE's BDA system to which all equity members are connected identifies the } \\
\text { beneficial owner of account trading. JSE systems also calculate member firm open } \\
\text { positions and liquid assets to ensure that firms can fulfill settlement responsibilities. } \\
\text { The JSE conducts an on-site inspection program of its member firms on a rotating } \\
\text { basis. }\end{array}$ \\
\hline Assessment & Fully Implemented \\
\hline Comments & $\begin{array}{l}\text { The FSB has the legal authority to review and approve all JSE rules except its listing } \\
\text { requirements, where FSB has only consultative authority. As recommended in the } \\
2008 \text { assessment update, the FSB is seeking an amendment to the SSA that would } \\
\text { provide it with full authority over JSE listing requirements. The FSB believes that } \\
\text { favorable action by Parliament is likely in } 2010 \text {. } \\
\text { Under the SSA the FSB may assume responsibility to perform essential regulatory } \\
\text { functions of the JSE and any functions incidental or conducive to the operation of an } \\
\text { exchange. Before taking on a duty, the FSB must notify the exchange, provide } \\
\text { reasons for the action to be taken and provide the exchange with time to demonstrate } \\
\text { why the responsibility should notbe assumed by the FSB. } \\
\text { While the JSE IT systems provide a wealth of information on the trading and traders in } \\
\text { its market, these systems are old. The JSE is fully aware of this problem and the } \\
\text { system replacement project (SRP) is one of its highest priorities. However, this effort } \\
\text { has been in progress for several years and completion is now estimated for } 2011 \text {. In } \\
\text { the interim, close attention must be paid to the reliability of the existing IT systems, }\end{array}$ \\
\hline
\end{tabular}




\begin{tabular}{|c|c|}
\hline & until the new systems are operational. \\
\hline $\begin{array}{l}\text { Principle } \\
27 .\end{array}$ & Regulation should promote transparency of trading. \\
\hline Description & $\begin{array}{l}\text { The JSE provides an electronic order driven market for equities with strict time and } \\
\text { price priority standards using the IT platform of the London Stock Exchange. It has an } \\
\text { open order book, and does not permit member firms to internalize customer orders. It } \\
\text { does permit large negotiated block trades to be reported to the trading system rather } \\
\text { than being executed through the central order book. } \\
\text { The JSE's SSF and Currency futures markets utilize a hybrid market model with } \\
\text { clients being able to choose either quote or order driven execution of trades. } \\
\text { The JSE provides a direct electronic interaction with free public access to best bid and } \\
\text { offer on a real-time, anonymous basis, and, for a fee, full access real-time to depth of } \\
\text { book in all listed securities. The JSE has initiated a program to list unique non- } \\
\text { standard derivatives, called the "can-do" option. The JSE states that this has improved } \\
\text { pricing and transparency. } \\
\text { When the JSE acquired the BESA, it adopted its trading platform. This is primarily a } \\
\text { trade reporting platform. Quotes are indicative rather than firm and trades are } \\
\text { negotiated bilaterally, typically by phone or through interdealer brokers. Members can } \\
\text { see full depth of book, while the general public has access to last trade information. } \\
\text { JSE requires that all trades must be reported within } 30 \text { minutes of execution. Both } \\
\text { systems maintain full audit trails for all reported trades. }\end{array}$ \\
\hline Assessment & Broadly Implemented \\
\hline Comments & $\begin{array}{l}\text { The systems in South Africa for trading in listed securities are robust and comparable } \\
\text { to international best practices. The challenge going forward will be to examine trading } \\
\text { in the OTC market. There is limited transparency concerning trading in the OTC } \\
\text { market. Historically, there was little OTC trading in South Africa. This is changing } \\
\text { rapidly. A variety of non-standard OTC derivative products linked to listed equities } \\
\text { have developed and trading appears to be growing. Hedging of these OTC products } \\
\text { accounts for a substantial percentage of daily trading in listed single stock futures. The } \\
\text { FSB should consider the implications of this development and examine how it can } \\
\text { fulfill its regulatory responsibilities and promote the development of an OTC market } \\
\text { with better transparency. } \\
\text { Section } 20 \text { of the Securities Services Act appears to provide the FSB with sufficient } \\
\text { authority to regulate OTC activities. The FSB has initiated a study of the OTC } \\
\text { derivative market to assess the need for greater transparency and regulatory } \\
\text { oversight. The FSB is encouraged to expand this study to include all aspects of the } \\
\text { OTC market, rather than limit it to OTC derivatives. }\end{array}$ \\
\hline $\begin{array}{l}\text { Principle } \\
28 .\end{array}$ & $\begin{array}{l}\text { Regulation should be designed to detect and deter manipulation and other unfair } \\
\text { trading practices. }\end{array}$ \\
\hline Description & $\begin{array}{l}\text { Primary responsibility for surveillance of market activity rests with the JSE. } \\
\text { The JSE market surveillance program for cash equities has a staff of } 3 \text { and a } \\
\text { sophisticated automated system for real-time monitoring of market trading. Price and } \\
\text { volume movements are monitored intraday and the staff has the capacity to identify } \\
\text { the account owners trading in cash equities. When unusual trading occurs, the staff } \\
\text { will contact the company and ascertain if price sensitive information must be } \\
\text { disclosed. If companies are aware of non-public information that is price sensitive, } \\
\text { they are required to issue an announcement to the public on the JSE SENS system. } \\
\text { The JSE has a broad principle requiring companies to disclose any information that } \\
\text { may have an impact on the price of the stock. While the initial analysis is the } \\
\text { responsibility of the company and its designated sponsor, if there is uncertainty over } \\
\text { the price sensitivity of the information, the JSE submits the question to its Issuer } \\
\text { Services Committee of outside authorities. The Committee's conclusion is dispositive. }\end{array}$ \\
\hline
\end{tabular}




\begin{tabular}{|c|c|}
\hline & $\begin{array}{l}\text { A cautionary statement must be published on SENS and posted on the company } \\
\text { website. If required, the JSE may temporarily halt trading or suspend trading in a } \\
\text { security for a maximum of } 30 \text { days and the JSE may renew a suspension for an } \\
\text { additional } 30 \text { days. Companies must be provided with an opportunity to respond prior } \\
\text { to initiation of the halt or suspension. } \\
\text { The Insider Trading Act of } 1998 \text { provided the FSB with the authority to initiate civil } \\
\text { actions for insider trading violations and require the repayment of illegal profits plus a } \\
\text { three-time penalty or refer matters for criminal prosecution. Since passage of the law, } \\
\text { the FSB has successfully brought } 30 \text { insider trading actions. The Securities Services } \\
\text { Act of } 2004 \text { has repealed the Insider Trading Act and has expanded the FSB authority } \\
\text { to more effectively address market manipulation cases (§75) and the publication of } \\
\text { false or misleading statements concerning listed companies ( } \S 76) \text {. Since its passage } \\
\text { the FSB has successfully completed } 20 \text { actions for various forms of market abuse, } \\
\text { including "wash trading" and "marking the close". The JSE surveillance team meets } \\
\text { weekly with FSB Directorate of Market Abuse staff to discuss anomalous trading } \\
\text { incidents. } \\
\text { The JSE imposes intraday price movement limits for trading on the agricultural } \\
\text { commodities market. } \\
\text { The FSB is a signatory to the IOSCO multi-lateral memorandum of understanding and } \\
\text { has entered into bilateral MOUs with } 50 \text { foreign authorities. }\end{array}$ \\
\hline Assessment & Fully Implemented \\
\hline Comments & $\begin{array}{l}\text { The surveillance programs at the JSE appear to be effective and appear to have a } \\
\text { strong working relationship with the FSB. One area where improvement may be } \\
\text { possible is in the immediate disclosure to the market of large block trades for a } \\
\text { member's own account, known as off-order book principal trades. While it may be } \\
\text { preferable to execute the off-order book principal trades outside the central order } \\
\text { book, to avoid distortive impacts on other trading, it is important for others in the } \\
\text { market to be aware of the price and size of the trade. The JSE reports that it is in the } \\
\text { process of deleting this rule. } \\
\text { As discussed previously, the Securities Services Act of } 2004 \text { applies to securities } \\
\text { listed for trading on a licensed exchange. Given the lack of information on OTC } \\
\text { activities and the large amount of OTC trading in listed equity linked derivative } \\
\text { products, the FSB should examine the need for additional authority to develop greater } \\
\text { OTC surveillance capacity. }\end{array}$ \\
\hline $\begin{array}{l}\text { Principle } \\
29 .\end{array}$ & $\begin{array}{l}\text { Regulation should aim to ensure the proper management of large exposures, default } \\
\text { risk and market disruption. }\end{array}$ \\
\hline Description & $\begin{array}{l}\text { All equity member firms are required to daily enter into JSE computer systems all cash } \\
\text { trades in listed securities as well as listed derivatives and separately report all OTC } \\
\text { derivatives trading. These entries must identify the client trading through the member } \\
\text { firm. This provides the JSE with robust data on customer trading in cash equities that } \\
\text { can be analyzed across more than one firm. It enables the JSE to identify large } \\
\text { customer positions, unusual trading patterns, and large open positions, long or short. } \\
\text { Directors of listed companies are required to disclose changes in beneficial } \\
\text { ownership, but the rule does not apply to company officers who are not directors. } \\
\text { Large beneficial owners of stock in a company must report changes in ownership to } \\
\text { the TRP and the company, which must make this public. } \\
\text { The JSE abolished its specific broker-customer margin requirements for credit } \\
\text { extensions on cash equity purchases in } 2005 \text { although member firms are still required } \\
\text { to effectively manage their credit risk. Listed derivatives trade on an approximate } 10\end{array}$ \\
\hline
\end{tabular}


percent cash margin but the margin requirement is specific to the volatility of the underlying securities. For unlisted transactions, the parties are free to agree on cash deposit/margin. Firm credit extensions will be reflected in firm cash positions reported to the JSE. Firm credit extensions occur frequently in contracts for difference (CFD's). These are comparable to single-stock futures, but traded OTC. As there is no legal transfer of ownership, the parties avoid a 25 bps transfer tax liability.

The JSE capital adequacy standard requires firms to discount large position concentrations, but the JSE cannot order a firm to reduce a large open position unless the position is causing a capital shortfall. JSE rules for derivatives trading require a daily mark to market with an adjustment to cash margin deposit as needed.

While the JSE is not constituted as a separate central counterparty, it acts as a central guarantor of all central order book equity trading on the JSE. Historically, the JSE reported that it had a "zero failed" trade record. Even after the global financial crisis, the JSE reports that it had only six trades that could not be settled in $T+5$. Each of these trades was rolled over for additional time and eventually settled.

In the event of a broad default by a member firm, the JSE has the authority under its rules, to transfer open positions and customer accounts from the defaulting firm to another member firm. Derivative transactions are cleared through the derivatives CCP, SAFCOM, a JSE subsidiary company. South African bankruptcy/ insolvency law recognizes a priority for unsettled trades.

A Joint SRO Incidents Committee has been established with the SROs and the FSB as members. In addition, the FSB and the SROs actively participate in the Financial Markets Stability Forum on which the SARB and other regulatory agencies are represented with the aim of responding to market emergencies.

\begin{tabular}{|l|l}
\hline Assessment & Broadly Implemented \\
\hline Comments & $\begin{array}{l}\text { As noted previously, the JSE has substantial capacity to immediately identify the } \\
\text { beneficial owner trading large positions in its listed market. }\end{array}$
\end{tabular}

Notwithstanding its lack of legal authority to act as a central counterparty, the JSE policy of guaranteeing successful settlement of trades appears to be functioning well.

As discussed previously, the amount of activity in the OTC market requires further analysis by the FSB. There is no accurate information on the size of this market and, there are no regulations on extension of credit to customers, firm concentration or size of trading with a single counterparty. The combination of limited transparency, no regulation on the extension of credit, no limitation on counterparty concentration and thus no control on counterparty default risk creates a potential for systemic risk if a counterparty is transacting substantial trading with more than one member firm and defaults. In 2009, a customer defaulted on a substantial OTC CFD position, which in turn caused the firm to default on a collateral call on the single stock future position it held as a hedge. No systemic failure occurred however, because under JSE rules the clearing firm for the introducing broker was liable for the position and this firm was sufficiently well capitalized to accept the loss. While, fortunately no market disruption resulted, the incident demonstrated the systemic risks posed by the unregulated activities in the OTC derivatives market. It is assumed that the FSB OTC study will carefully consider whether there is a need to mandate a minimum level of or margin or collateral that must be posted and maintained in the OTC market.

Principle Systems for clearing and settlement of securities transactions should be subject to 30. regulatory oversight, and designed to ensure that they are fair, effective and efficient and that they reduce systemic risk. 
clearance and the guarantee of equity settlement functions (Strate settles equity trades). Derivatives trading on the JSE clears through its SAFCOM subsidiary.

Bond trading is largely bilateral, with bilateral settlement through Strate, As the central securities depository (CSD), it has broad authority to establish rules, approved by the FSB, and to inspect and discipline its participants. South African law provides for nonmandatory immobilization and dematerialization of securities. Strate estimates that more than 95 percent of listed equity securities are dematerialized and over 70 percent of debt issues are dematerialized.

Listed equities are cleared by the JSE and settled by Strate on a T+5 cycle. The JSE acts as settlement guarantor of all central order book equity trades on a $T+5$ cycle. The JSE processes all trade matching and after matching is completed submits the settlement instruction to Strate. All settlement is delivery versus payment at three points in the day.

SAFCOM is licensed as the clearinghouse for all JSE-listed derivative trades and clears on a cash settled net basis except for agricultural derivatives that are physically settled. Seven members are full participants of Strate and operate as settlement agents, with cash processed through the central bank system in central bank funds.

Strate operates two fully redundant IT systems and states that it can transfer between systems within minutes. The systems are in separate locations. Communications with member banks operates across the global Swift system. The FSB reports that there was one system outage in the past year, due to the introduction of a new software release.

Strate operates an inspection program of its members.

There is no standard on OTC clearance and settlement. The parties may bilaterally agree on settlement terms. Large block equity trades can be executed off the JSE central order book (to avoid market impact caused by a large block trade) but they are still settled bilaterally through Strate. All trades in listed securities by persons who are in the business of buying and selling securities must be executed through the JSE, unless the trade is between financial institutions trading for their own account. In the latter case, the trade must be reported to the FSB.

As there is a substantial amount of trading in dual listed equities and debt in London, Strate must transfer securities out of its depository to London on a daily basis. An automated registry system has been created to facilitate this process.

Assessment Principle not rated

\begin{tabular}{l|l} 
Comments & This FSAP update did not include a full analysis, applying the CPSS/IOSCO
\end{tabular} framework, of the clearance and settlement system in South Africa. Accordingly no rating is assigned.

As previously indicated, adoption of a $T+3$ cycle for cash equities is a priority for this market and has been initiated by the FSB as a JSE license renewal requirement. However the conversion to $T+3$ has been substantially delayed due to delays in the JSE system replacement program. The current schedule calls for completion of the IT system replacement program in 2011 and conversion to $\mathrm{T}+3$ in the year following. This may be optimistic.

While the JSE or Strate does not have the legal authority of a central counterparty, ordinarily a significant weakness, this does not appear to be a substantial problem as a practical matter. This is because the policy of the JSE to act as guarantor of all trades on its markets, backed by a large cash reserve and its guarantee fund. In 2008 , 
the JSE continued its record of a zero fail rate on settlement, due to its policy of replacing any failures to deliver from the market on $\mathrm{T}+4$. Even during the financial crisis, the JSE was able to continue to avoid a significant number of failures (six total). This demonstrates that the system appears to function well, even during periods of market stress.

However the global best practice is based upon a $T+3$ cycle and the imprimatur and backing of the legal powers of novation. Notwithstanding the record of the current system, for international recognition the JSE should consider obtaining formal CCP authority. 